Cover photo: Morning mist on the Little Miami River at Miamiville, Ohio. Photo by Eric B. Partee, Little Miami Inc., published with permission. 
U.S. Department of the Interior

U.S. Geological Survey

Trace Elements and Synthetic Organic

Compounds in Streambed Sediment and Fish

Tissue in the Great and Little Miami River

Basins, Ohio and Indiana,1990-98

By Stephanie D. Janosy

Water-Resources Investigations Report 02-4305

National Water-Quality Assessment Program 


\section{U.S. Department of the Interior \\ GALE A. NORTON, Secretary}

U.S. Geological Survey

Charles G. Groat, Director

Any use of trade, product, or firm names is for descriptive purposes only and does not imply endorsement by the U.S. Government.

For additional information write to:

District Chief

U.S. Geological Survey

6480 Doubletree Avenue

Columbus, OH 43229-1111

Copies of this report can be purchased from:

U.S.Geological Survey

Branch of Information Services

Box 25286

Denver, CO 80225-0286

Columbus, Ohio

2003 


\section{FOREWORD}

The U.S. Geological Survey (USGS) is committed to serve the Nation with accurate and timely scientific information that helps enhance and protect the overall quality of life, and facilitates effective management of water, biological, energy, and mineral resources. Information on the quality of the Nation's water resources is of critical interest to the USGS because it is so integrally linked to the long-term availability of water that is clean and safe for drinking and recreation and that is suitable for industry, irrigation, and habitat for fish and wildlife. Escalating population growth and increasing demands for the multiple water uses make water availability, now measured in terms of quantity and quality, even more critical to the long-term sustainability of our communities and ecosystems.

The USGS implemented the National Water-Quality Assessment (NAWQA) Program to support national, regional, and local information needs and decisions related to waterquality management and policy. Shaped by and coordinated with ongoing efforts of other Federal, State, and local agencies, the NAWQA Program is designed to answer: What is the condition of our Nation's streams and ground water? How are the conditions changing over time? How do natural features and human activities affect the quality of streams and ground water, and where are those effects most pronounced? By combining information on water chemistry, physical characteristics, stream habitat, and aquatic life, the NAWQA Program aims to provide science-based insights for current and emerging water issues. NAWQA results can contribute to informed decisions that result in practical and effective water-resource management and strategies that protect and restore water quality.

Since 1991, the NAWQA Program has implemented interdisciplinary assessments in more than 50 of the Nation's most important river basins and aquifers, referred to as Study Units. Collectively, these Study Units account for more than 60 percent of the overall water use and population served by public water supply, and are representative of the Nation's major hydrologic landscapes, priority ecological resources, and agricultural, urban, and natural sources of contamination.

Each assessment is guided by a nationally consistent study design and methods of sampling and analysis. The assessments thereby build local knowledge about waterquality issues and trends in a particular stream or aquifer while providing an understanding of how and why water quality varies regionally and nationally. The consistent, multi-scale approach helps to determine if certain types of water-quality issues are isolated or pervasive, and allows direct comparisons of how human activities and natural processes affect water quality and ecological health in the Nation's diverse geographic and environmental settings. Comprehensive assessments on pesticides, nutrients, volatile organic compounds, trace metals, and aquatic ecology are developed at the national scale through comparative analysis of the Study-Unit findings.

The USGS places high value on the communication and dissemination of credible, timely, and relevant science so that the most recent and available knowledge about water 
resources can be applied in management and policy decisions. We hope this NAWQA publication will provide you the needed insights and information to meet your needs, and thereby foster increased awareness and involvement in the protection and restoration of our Nation's waters.

The NAWQA Program recognizes that a national assessment by a single program cannot address all water-resource issues of interest. External coordination at all levels is critical for a fully integrated understanding of watersheds and for cost-effective management, regulation, and conservation of our Nation's water resources. The Program, therefore, depends extensively on the advice, cooperation, and information from other Federal, State, interstate, Tribal, and local agencies, non-government organizations, industry, academia, and other stakeholder groups. The assistance and suggestions of all are greatly appreciated.

Robert M. Hirsch

Associate Director for Water 


\section{CONTENTS}

Abstract

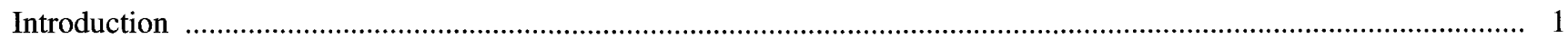

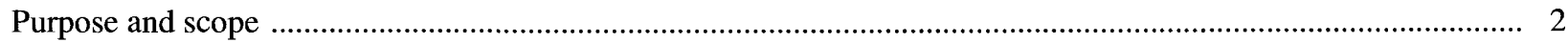

Description of the Great and Little Miami River Basins study unit ............................................................... 2

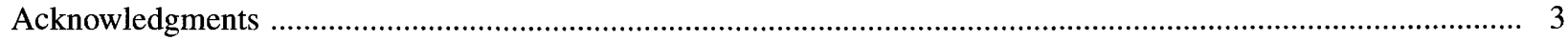

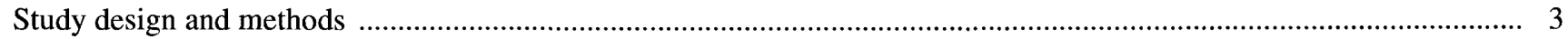

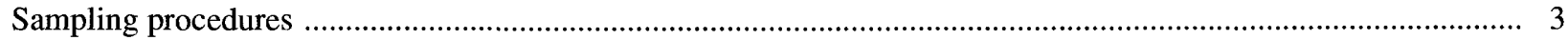

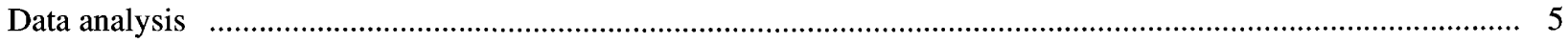

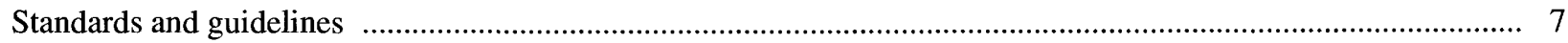

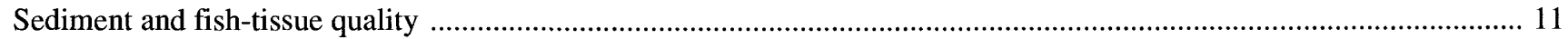

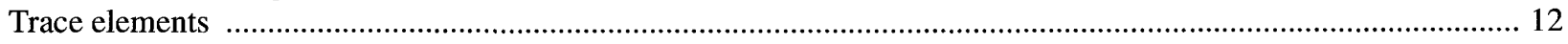

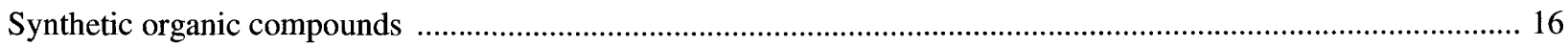

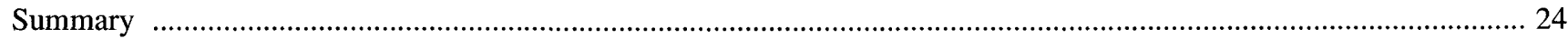

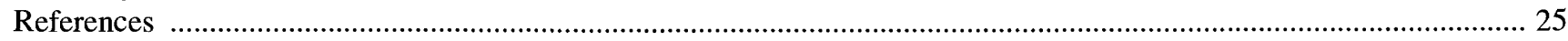

Appendix A-Results of a national assessment of mercury contamination of aquatic ecosystems ................................ 28

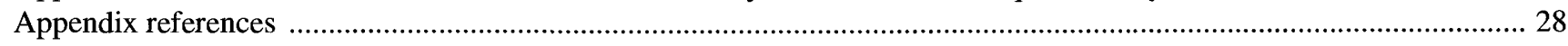

\section{ILLUSTRATIONS}

1. Map showing the Great and Little Miami River Basins study unit, Ohio and Indiana. ........................................... 4

2. Graph showing percentage of sites where trace elements and synthetic organic compounds were detected within the Great and Little Miami Rivier Basins, Ohio and Indiana, 1990-98 ..................................................... 11

3. Graph showing arsenic concentrations as a function of sediment clay content at the Great and Little Miami River Basin study unit sampling locations, Ohio and Indiana, 1998............................... 13

4. Graph showing concentrations of selected trace elements at Great and Little Miami River sites compared to Canadian Sediment-Quality Guidelines and selected 1991 and 1994 national NAWQA study units.

5. Map showing location of streambed-sediment samples exceeding Canadian Sediment-Quality Guideline Probable Effect Levels (PELs) and trace-element detections in fish-tissue samples in the Great and Little Miami River Basins, Ohio and Indiana, 1990-98.

6. Graph showing concentrations of selected organochlorine insecticides at Great and Little Miami River Basins streambed-sediment sites compared to Canadian Sediment-Quality Guidelines and data from selected 1991 and 1994 national NAWQA study units.

7. Map showing location of streambed-sediment samples exceeding Canadian Sediment-Quality Guideline Probable Effect Levels (PELs) and fish-tissue samples exceeding New York Fish Flesh Criteria (NYFFC) for organochlorine insecticides in the Great and Little Miami River Basins, Ohio and Indiana, 1990-98.

8. Graph showing concentrations of selected organochlorine insecticides and total polychlorinated biphenyls at Great and Little Miami River Basins fish-tissue sites compared to New York Fish Flesh Criteria (NYFFC) and selected 1991 and 1994 national NAWQA study units.

9. Map showing location of sediment samples exceeding Canadian Sediment-Quality Guideline Probable Effect Levels (PELs) and fish-tissue samples exceeding New York Fish Flesh Criteria (NYFFC) for polychlorinated biphenyls in the Great and Little Miami River Basins, Ohio and Indiana, 1990-98.

10. Graph showing concentrations of selected semivolatile organic compounds at Great and Little Miami River Basins streambed-sediment sites compared to Canadian Sediment-Quality Guideline Probable Effect Levels (PELs), and data from selected 1991 NAWQA study units. 
11. Map showing location of streambed-sediment samples exceeding Canadian Sediment-Quality Guideline Probable Effect Levels (PELs) for semivolatile organic compounds in the Great and

Little Miami River Basins, Ohio and Indiana, 1990-98.

A1. Graph showing comparison of mercury concentrations in fish-fillet samples in the Great and Little Miami River Basins study unit to range and median concentrations from 21 national NAWQA study units.

\section{TABLES}

1. Description of sampling sites in the Great and Little Miami River Basins study unit, Ohio and Indiana

2. Constituents analyzed for in streambed sediment and fish tissue by the National Water-Quality Assessment Program

3. Maximum number of streambed-sediment and fish-tissue sites per agency incorporated for analyses

4. Canadian Sediment Quality Guidelines and New York Fish Flesh Criteria for trace elements, organochlorine insecticides, total polychlorinated biphenyls, and semivolatile organic compounds including common sources, uses, and examples of potential adverse effects to wildlife

5. Particle-size distribution and organic-carbon concentrations at Great and Little Miami River Basins streambed-sediment sampling sites, Ohio and Indiana, 1998

A1. Mercury concentrations in fish fillets, bed sediment, and surface water at selected sampling locations in the Great and Little Miami River Basins 


\begin{tabular}{rll}
\hline Multiply & \multicolumn{1}{c}{ By } & To obtain \\
\hline meter $(\mathrm{m})$ & $3.281 \times 10^{0}$ & foot \\
centimeter $(\mathrm{cm})$ & $3.937 \times 10^{-1}$ & inch \\
millimeter $(\mathrm{mm})$ & $3.937 \times 10^{-2}$ & inch \\
micrometer $(\mu \mathrm{m})$ & $3.937 \times 10^{-5}$ & inch \\
square mile $\left(\mathrm{mi}^{2}\right)$ & $2.590 \times 10^{0}$ & square kilometer \\
$\operatorname{liter}(\mathrm{L})$ & $2.642 \times 10^{-1}$ & gallon \\
\hline
\end{tabular}

Abbreviated chemical-quahity units used in this report: Concentrations of chemical constituents in sediment and fish tissue are given in units of milligrams per kilogram $(\mathrm{mg} / \mathrm{kg})$, micrograms per kilogram $(\mu \mathrm{g} / \mathrm{kg})$, or nanograms per gram (ng/g). Concentrations of mercury in surface water are given in nanograms per liter $(\mathrm{ng} / \mathrm{L})$.

Other abbreviations used in this report:

CERCLIS Comprehensive Environmental Response Compensation and Liability Information System

DDD Dichlorodiphenyldichloroethane

DDE Dichlorodiphenyldichloroethylene

DDT Total dichlordiphenyltrichloroethane

IDEM Indiana Department of Environmental Management

ISQG Canadian Interim Sediment Quality Guidelines

MIAM Great and Little Miami River Basins

NAWQA National Water-Quality Assessment

NPL National Priority List

NWQL U.S. Geological Survey National Water Quality Laboratory

NYFFC New York Fish Flesh Criteria

OEPA Ohio Environmental Protection Agency

p Binomial probability

PAH Polycyclic aromatic hydrocarbons

PCB Total polychlorinated biphenyls

PEL Probable Effect Level

rho Spearman correlation coefficient

RM River mile

SOC Synthetic organic compound

SVOC Semivolatile organic compound

SQG Sediment-quality guideline

TEL Threshold Effect Level

TRI Toxic Release Inventory

USGS U.S. Geological Survey 



\title{
Trace Elements and Synthetic Organic Compounds in Streambed Sediment and Fish Tissue in the Great and Little Miami River Basins, Ohio and Indiana, 1990-98
}

\author{
By Stephanie D. Janosy
}

\begin{abstract}
Streambed-sediment and fish-tissue samples were collected at eight sites in the Great and Little Miami Basins as part of the U.S. Geological Survey's National Water Quality Assessment Program. The samples were analyzed for trace elements and synthetic organic compounds, including organochlorine insecticides, polychlorinated biphenyls (PCBs), and semivolatile compounds (SVOCs). Data from stateagency investigations within the study unit (more than 200 sites) were incorporated to gain a broader perspective of the occurrence and distribution of contaminants in the study unit. All data were compared to streambed-sediment-quality guidelines and fish-tissue guidelines to identify elevated contaminant concentrations. Guideline exceedances were plotted on distribution maps to identify areas in the study unit that may be of potential concern for wildlife health.
\end{abstract}

Several trace elements were detected in both sediment and fish-tissue samples. In sediment, lead and zinc were most frequently detected at levels that may have adverse effects on aquatic organisms. Generally, only one of the trace elements analyzed for per site exceeded concentrations above which adverse biological effects are frequently anticipated.

Organochlorine insecticides were infrequently detected in sediment or fish tissue throughout the study unit. More organochlorine insecticides were detected in fish tissues than in sediment; however, more guidelines were exceeded in sediment. No distinct geographic overlap between sediment and fishtissue sites was evident with respect to elevated organochlorine insecticide concentrations. Sediment- quality guideline exceedances were generally widespread throughout the study unit, whereas fish-tissue guidelines were exceeded only on the Mad River.

PCBs were detected more often in fish tissue than in sediment throughout the study unit. Elevated PCB concentrations in fish tissue were common and widespread. No distinct geographic overlap of PCB exceedances was evident between sediment and fishtissue sites.

In sediments, elevated concentrations were detected most often for SVOCs, particularly for polycyclic aromatic hydrocarbons (PAHs). Areas where SVOC guidelines were frequently exceeded include the Great Miami River main stem from Dayton to south of Hamilton, and the Upper Little Miami River Basin in Greene County.

Overall, a higher frequency of trace-element detections in fish tissue and sediment trace-element guideline exceedances was found in the Great Miami River Basin than in the Little Miami River Basin. Organochlorine insecticide guidelines for fish tissue and sediment, as well as PCB and SVOC guidelines for sediment also were exceeded more frequently in the Great Miami River Basin. PCB guideline exceedances for fish tissue were found more often in the Little Miami River Basin.

\section{Introduction}

In 1991, the U.S. Geological Survey (USGS) began the National Water-Quality Assessment (NAWQA) Program. Long-term goals of the NAWQA Program are to describe the status and trends in the water quality of a large, repre- 
sentative part of the Nation's surface- and ground-water resources and to provide a sound scientific understanding of the primary natural and human factors affecting the quality of these resources (Hirsch and others, 1988). NAWQA study-unit investigations, which are long term and cyclic, first began in 1991 and were followed by additional study unit investigations beginning in 1994 and 1997. The Great and Little Miami River Basins is one of more than 50 study units originally chosen by the NAWQA Program to represent the diverse geography, water resources, and land and water uses in the Nation. The Great and Little Miami River Basins study unit (MIAM) includes three large watersheds in the Ohio River Basin, largely agricultural watersheds affected by two major urban areas and rapid urbanization, and a heavily used buried-valley aquifer system that is one of the most productive in the Nation (Rowe and Baker, 1997).

An integral part of the NAWQA Program is to investigate and evaluate trends of occurrence and distribution of targeted contaminants in streambed sediment and fish tissue (Shelton and Capel, 1994). Contaminant concentrations in sediment and tissue can be several orders of magnitude higher than in water and may be detected even when concentrations in the water column are too low for detection (Rand, 1995; Crawford and Luoma, 1994). Many of the more persistent hydrophobic compounds are removed from the water column as they sorb to suspended particles and organic material that may become part of the streambed sediment. Contaminants that can accumulate in sediment include trace elements, pesticides, and industrial chemicals (Lyman and others, 1987). Aquatic organisms are exposed to contaminants by direct exposure or by consuming benthic biota that have been exposed to the contaminant (Rand, 1995). Concentrations in fish tissues provide a direct measure of bioavailability and can be used as an indicator of potential health risks to fish-eating wildlife (Crawford and Louma, 1994).

To determine contaminant distribution and occurrence across the Nation, the NAWQA Program targets two important chemical classes: synthetic organic compounds (SOCs) and trace elements. SOCs include organochlorine insecticides, polychlorinated biphenyls (PCBs), and other semivolatile organic compounds (SVOCs) that were widely used from the 1940s to the 1970s and 1980s before many were restricted or banned. Many SOCs are toxic and may act as carcinogens or endocrine disruptors. Trace elements are naturally occurring and can be redistributed in the environment through human activities such as fossil fuel combustion. They may enter aquatic environments through point- and nonpoint-source releases and atmospheric deposition. For aquatic biota, trace elements of greatest concern are copper, zinc, cadmium, mercury, and lead (Rand, 1995). These elements are toxic to organisms above specific threshold concentrations, but many of these elements (for example, copper and zinc) are necessary for metabolism at lower concentrations. Lead, cadmium, and mercury have no known biological function.

\section{Purpose and scope}

This report summarizes streambed sediment and fish-tissue data collected by the MIAM personnel during summer 1998. In addition, data previously collected by state agencies within the study unit are incorporated to gain a better perspective of the occurrence and distribution of contaminants.

Contaminant data are presented and interpreted in four ways. First, presence/absence and frequency of contaminant occurrence at MIAM sampling stations are described. Second, MIAM contaminant concentrations are compared to concentrations found by other NAWQA study units throughout the Nation. Third, data from state agencies are incorporated to give a regional perspective of occurrence. Fourth, data from all agencies are compared to sediment-quality guidelines and fish-tissue guidelines to identify compounds that exceed published limits and, by means of occurrence and distribution maps, to identify areas that may be a concern for wildlife health.

For this report, data collected by MIAM NAWQA personnel are described as "MIAM data." "National NAWQA data" refers to data collected by other NAWQA study units (1991, 1994, or 1997), where available. "Stateagency data" describes data collected by the Ohio Environmental Protection Agency (OEPA) and Indiana Department of Environmental Management (IDEM); "study-unit data" defines all data collected in the study unit by MIAM, OEPA, and IDEM.

Relations between sediment and tissue concentrations are difficult to determine and were not attempted in this report because of the many factors that affect the behavior, fate, and transport of trace elements and synthetic organic compounds. Such factors may include chemical speciation, water characteristics, physical features such as dams, antagonistic effects, and adsorption and desorption rates. Fish species, migration, feeding preferences, metabolic rates, and lipid content also must be taken into consideration.

\section{Description of the Great and Little Miami River Basins study unit}

The Great and Little Miami River Basins cover approximately $7,350 \mathrm{mi}^{2}$. Three large river systems drain the study unit. The Great Miami River (drainage area, $4,124 \mathrm{mi}^{2}$ ) and the Little Miami River (drainage area, 1,756 $\mathrm{mi}^{2}$ ) are in southwestern Ohio, and the Whitewater River (drainage area, $1,474 \mathrm{mi}^{2}$ ) is in southeastern Indiana (fig.1). The Whitewater River exits Indiana in Dearborn County and joins the Great Miami|River in Hamilton County near Cin- 
cinnati. Both the Great and Little Miami Rivers drain directly into the Ohio River. Major tributaries in the study unit include the Mad and Stillwater Rivers in the Great Miami River Basin, East Fork Little Miami River in the Little Miami River Basin, and East and West Fork Whitewater Rivers in the Whitewater River Basin. Streamflow in the study unit is affected by five flood-retention dams and eight lowhead dams in the Great Miami River Basin, one dam on the East Fork Whitewater River, and four dams on both the East Fork Little Miami River and main stem of the Little Miami River (Harrington, 1999).

The study unit spans two ecoregions, the Eastern Corn Belt Plains and the Interior Plateau (Debrewer and others, 2000). Approximately 79 percent of land is used for agricultural activities, primarily row-crop production of corn, soybeans, and wheat. Principal livestock raised are swine, cattle, and poultry. Residential, commercial, and industrial land uses make up 13 percent of the area, whereas the remaining area consists of forests ( 7 percent) and water bodies or wetlands ( 1 percent). Major industries, which are concentrated along the Dayton-Cincinnati corridor, produce automobile parts, business and computer equipment, chemicals, household goods, paper products, and processed foods and beverages.

In 1995, the estimated population of the study unit was approximately 2.8 million, mostly concentrated near the largest cities: Cincinnati, Dayton, and Hamilton, Ohio (Rowe and Baker, 1997). A complete description of the environmental setting for the study unit can be found in Debrewer and others (2000).

\section{Acknowledgments}

Special thanks are extended to James Stahl (IDEM) for his compilation of data and to Dennis Mishne (OEPA) for compilation of data and review of the report. The author thanks USGS personnel Ralph Haefner, Daniel Button, Gary

Rowe, Robin Brightbill, and Dorene MacCoy for their critical reviews of the report. The author also acknowledges Lee Hwang of the USGS for his assistance with data and map preparation.

\section{Study design and methods}

Streambed-sediment and fish-tissue samples represented in the MIAM data sets were collected during the summer at base flow. Samples were collected from eight established MIAM sites representing five agricultural, one urban, and two mixed-land-use settings. Mixed-land-use settings, hereafter referred to as mixed settings, are defined as sites located downstream from drainage basins that are large and complex and often contain multiple environmental settings. (Shelton, 1994). A summary of sampling sites is listed in table 1. Each tissue sample consisted of four to eight liver composites for trace-element analyses and four to eight whole-fish composites for organic analyses. To allow for comparisons between MIAM and other NAWQA study units, the common carp (Cyprinus carpio) was selected as the target species because of its national abundance and relative ease to collect. A composite of streambed-sediment samples was collected from several depositional zones within the reach sampling boundaries of approximately $100 \mathrm{~m}$ in length, and then divided into two samples for further processing for trace-element and synthetic-organiccompound analyses.

Fish tissue was analyzed for 22 trace elements and 28 organic compounds (organochlorine insecticides, industrial compounds, and a chlorinated herbicide); sediments were analyzed for 46 trace elements, 33 organochlorine insecticides plus polychlorinated biphenyls (PCBs), and 65 industrial organic compounds. A complete list of chemicals analyzed by NAWQA is given in table 2 .

\section{Sampling procedures}

The sampling procedures used for sampling streambed sediment and tissue are briefly described below. A more detailed description of sampling procedures for streambed sediment can be found in Shelton and Capel (1994). Laboratory procedures used to analyze organic compounds and semivolatile organic compounds in streambed sediment are described in Forman and others (1995) and Furlong and others (1996), respectively. Protocols used for collecting and processing fish tissue for the analysis of trace elements and synthetic organic compounds are described in detail in Crawford and Luoma (1994). Sediment and tissue data are published in Shindel and others (1999) and U.S. Geological Survey (2002).

Sediment. Fine-grained sediment samples were collected from 5 to 10 depositional zones within the sampling reach. Sediment was collected at 5 to 10 locations within each depositional zone. A total volume of $1.5 \mathrm{~L}$ of wet sediment was collected from the top layer $(1 \mathrm{~cm})$ of the sediment surface using a Teflon spatula. To control crosscontamination between trace-element and organic samples, field personnel wore latex gloves and used separate sampling equipment for each type of sample. Sediments collected for trace-element analysis were processed through a $63-\mu \mathrm{m}$ mesh nylon sieve held in a plastic frame over a plastic bottle. Samples collected for analysis of organic compounds were processed through a $2.0-\mathrm{mm}$ stainless steel sieve over a baked amber glass jar. Samples were shipped on ice to the U.S. Geological Survey National Water Quality Laboratory (NWQL) for analysis.

Fish tissue. Common carp were collected with towed electrofishing gear at all locations with the exception of the Great Miami River at Hamilton, a nonwadeable site, which 


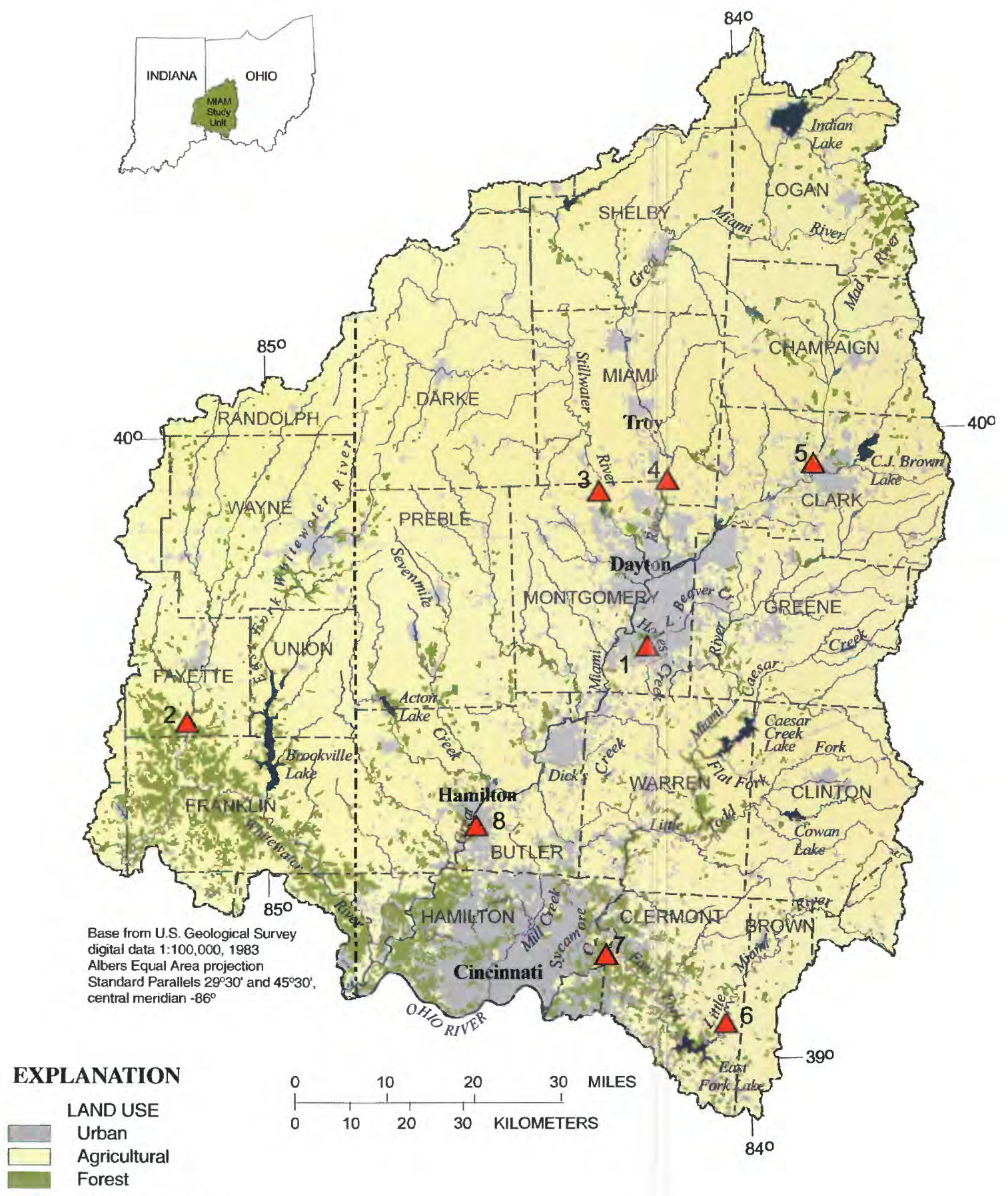

$\triangle$ SAMPLING SITE

Figure 1. The Great and Little Miami River Basins study unit, Ohio and Indiana. 
Table 1. Description of sampling sites in the Great and Little Miami River Basins study unit, Ohio and Indiana [Major land use percentages were calculated from National Land Cover Data (1992); mi $^{2}$, square miles]

\begin{tabular}{|c|c|c|c|c|c|c|c|c|c|}
\hline \multirow{2}{*}{$\begin{array}{l}\text { Figure } 1 \\
\text { locationn } \\
\text { umber }\end{array}$} & \multirow[b]{2}{*}{ Station number } & \multirow[b]{2}{*}{ Station name } & \multirow[b]{2}{*}{ Latitude } & \multirow[b]{2}{*}{ Longitude } & \multirow{2}{*}{$\begin{array}{r}\text { Drainage } \\
\text { area }\left(\mathbf{m i}^{2}\right)\end{array}$} & \multicolumn{4}{|c|}{ Major land use (percent) } \\
\hline & & & & & & Urban & $\begin{array}{l}\text { Agricult } \\
\text { ure }\end{array}$ & Forest & Other \\
\hline \multicolumn{10}{|c|}{ Urban site } \\
\hline 1 & 393944084120700 & $\begin{array}{l}\text { Holes Creek at } \\
\text { Kettering, Ohio }\end{array}$ & $39^{\circ} 39^{\prime} 44^{\prime \prime}$ & $84^{\circ} 12^{\prime} 07^{\prime \prime}$ & 20 & 61.9 & 28.5 & 9.0 & 0.6 \\
\hline \multicolumn{10}{|c|}{ Agricultural sites } \\
\hline 2 & 393259085101200 & $\begin{array}{l}\text { Whitewater River near } \\
\text { Nulltown, Ind. }\end{array}$ & $39^{\circ} 32^{\prime} 59^{\prime \prime}$ & $85^{\circ} 10^{\prime} 12^{\prime \prime}$ & 533 & 1.9 & 88.0 & 9.1 & 1.0 \\
\hline 3 & 395433084175300 & $\begin{array}{l}\text { Stillwater River on Old } \\
\text { Springfield Rd near } \\
\text { Union, Ohio }\end{array}$ & $39^{\circ} 54^{\prime} 33^{\prime \prime}$ & $84^{\circ} 17^{\prime} 53^{\prime \prime}$ & 643 & 2.1 & 91.6 & 5.8 & 0.5 \\
\hline 4 & 395534084091400 & $\begin{array}{l}\text { Great Miami River near } \\
\text { Tipp City, Ohio }\end{array}$ & $39^{\circ} 55^{\prime} 34^{\prime \prime}$ & $84^{\circ} 09^{\prime} 14^{\prime \prime}$ & 1,128 & 3.3 & 86.7 & 8.6 & 1.4 \\
\hline 5 & 395650083504400 & $\begin{array}{l}\text { Mad River near Hwy } 41 \\
\text { near Springfield, } \\
\text { Ohio }\end{array}$ & $39^{\circ} 56^{\prime} 50^{\prime \prime}$ & $84^{\circ} 50^{\prime} 44^{\prime \prime}$ & 319 & 3.1 & 81.8 & 14.6 & 0.5 \\
\hline 6 & 03246400 & $\begin{array}{l}\text { East Fork Little Miami } \\
\text { River near } \\
\text { Williamsburg, Ohio }\end{array}$ & $39^{\circ} 03^{\prime} 32^{\prime \prime}$ & $84^{\circ} 03^{\prime} 05^{\prime \prime}$ & 234 & 1.3 & 85.9 & 12.2 & 0.6 \\
\hline \multicolumn{10}{|c|}{ Mixed-land-use sites } \\
\hline 7 & 03245500 & $\begin{array}{l}\text { Little Miami River at } \\
\text { Milford, Ohio }\end{array}$ & $39^{\circ} 10^{\prime} 11^{\prime \prime}$ & $84^{\circ} 17^{\prime} 52^{\prime \prime}$ & 1,202 & 9.2 & 73.2 & 16.5 & 1.1 \\
\hline 8 & 392246084340100 & $\begin{array}{l}\text { Great Miami River } \\
\text { below Hamilton, } \\
\text { Ohio }\end{array}$ & $39^{\circ} 22^{\prime} 46^{\prime \prime}$ & $84^{\circ} 34^{\prime} 01^{\prime \prime}$ & 3,636 & 7.7 & 80.9 & 10.4 & 1.0 \\
\hline
\end{tabular}

analysis, four to eight livers were removed with Tefloncoated stainless steel forceps, weighed, and composited in a glass jar. To avoid sample contamination, field personnel wore vinyl gloves and used separate sampling equipment for external and internal incisions. For synthetic organic compound samples, four to eight whole fish were tagged and individually wrapped in aluminum foil. All samples were sealed in plastic bags and shipped on dry ice to the NWQL for analysis. Analytical methods for tissue are published in Hoffman (1996) and Leiker and others (1995).

\section{Data analysis}

To better define regional occurrence and distribution of contaminants, post-1990 data collected in the study unit by state agencies were combined with the MIAM data for analyses (table 3). Sediment and tissue data were compiled from reports and electronic data files supplied by OEPA and IDEM (D. Mishne, Ohio Environmental Protection Agency, written commun., 2001; and J. Stahl, Indiana Department of Environmental Management, written commun., 2001). This aggregation of streambed-sediment and fish-tissue data from multiple sources was complicated by several factors, including (1) differences in field methods, (2) variations in analytical reporting limits for individual chemicals and over time, and (3) variations in target species and (or) target organs used for tissue analyses. For example, sediment samples collected by the USGS were sieved in the field to obtain the fine-grained fraction of sediment, which generally contains higher concentrations of adsorbed chemicals than coarse fractions do. Therefore, USGS analyses may report higher concentrations of some contaminants in relation to OEPA and IDEM data, which are based on analyses of unsieved samples. Laboratory methods at all agencies varied and were continuously being revised and improved, yielding multiple detection limits among agencies and, in some cases, for individual chemicals. State-agency field and laboratory methods are published in agency manuals (Indiana Department of Environmental Management, 1992 and 1999; Ohio Environmental Protection Agency, 1989, 1995, 1996 and 1997b).

Variations in tissue types (fillet, whole fish, or liver) or species collected varied among the agencies and was dependent on the objective of the individual monitoring program. For example, most studies monitoring contaminant concentration in fish tissue focus on possible risks to human health and therefore analyze fillets, the edible portion of the fish, from sportfish species such as smallmouth bass. 
Table 2. Constituents analyzed for in streambed sediment and fish tissue by the National Water-Quality Assessment Program

$\left[{ }^{*}\right.$, constituents analyzed for in tissue; **, tissue only; Modified from Shelton and Capel, 1994. Compounds in bold are Priority Toxic Pollutants (U.S.

Environmental Protection Agency, 1999); •, Chromium III and VI only; $\nabla$, Chlordane; $\diamond$, alpha-Endosulfan and beta-Endosulfan].

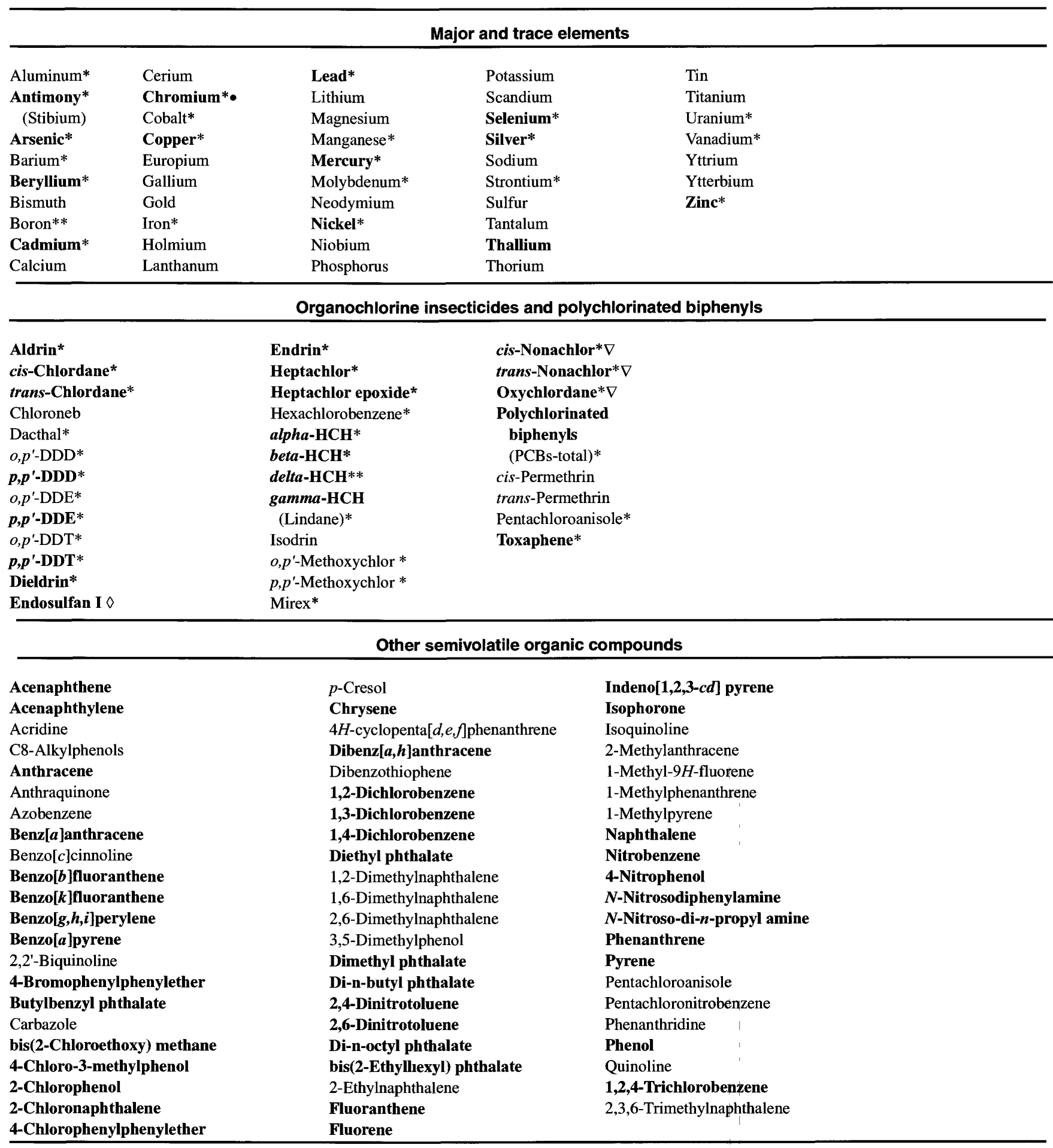


Table 3. Maximum number of streambed-sediment and fish-tissue sites per agency incorporated for analyses [Number of samples vary per constituent. PCBs, polychlorinated biphenyls; SVOCs, semivolatile organic compounds; --, no whole-body samples]

\begin{tabular}{|c|c|c|c|c|c|c|c|}
\hline \multirow{2}{*}{ Data source } & \multicolumn{4}{|c|}{ Number of sediment sites } & \multicolumn{3}{|c|}{ Number of fish-tissue sites } \\
\hline & $\begin{array}{c}\text { Trace } \\
\text { elements }\end{array}$ & $\begin{array}{l}\text { Organochlorine } \\
\text { insecticides }\end{array}$ & PCBs & Svocs & $\begin{array}{c}\text { Trace } \\
\text { elements }\end{array}$ & $\begin{array}{l}\text { Organochlorine } \\
\text { insecticides }\end{array}$ & PCBs \\
\hline \multicolumn{8}{|l|}{ U.S. Geological Survey } \\
\hline MIAM NAWQA & 8 & 8 & 8 & 8 & 8 & 8 & 8 \\
\hline \multicolumn{8}{|l|}{ State Agency } \\
\hline $\begin{array}{l}\text { Ohio Environmental } \\
\text { Protection Agency }\end{array}$ & 227 & 176 & 179 & 142 & 33 & 36 & 36 \\
\hline $\begin{array}{l}\text { Indiana Department of } \\
\text { Environmental } \\
\text { Management }\end{array}$ & 4 & 8 & 8 & 5 & -- & -- & -- \\
\hline
\end{tabular}

Whole-fish samples were typically used when the objective of a program was to assess the health risk to fish-eating wildlife; such programs commonly target species such as the common carp or a sucker species. NAWQA Program objectives are to determine contaminant concentrations that may pose a risk to wildlife health; consequently, whole fish were used in organic analyses. For trace-element analyses, however, whole-fish and fillet samples may be insensitive monitors of trace-element concentrations (with the exception of mercury). Polar substances such as cadmium, lead, and zinc do not readily bioaccumulate in fish muscle (fillets), where less polar elements tend to accumulate. Instead, these elements concentrate in various organs, particularly the liver, which commonly has higher metal concentrations than other organs and is therefore a good indicator of metal concentrations (Crawford and Louma, 1994). To eliminate variability in contaminant concentration among tissue types sampled and among species because of migration, feeding, or metabolism rates, only whole-carp and liver data are included in this report.

Samples with concentrations less than the reporting limit were treated as nondetections, and concentrations (including estimated concentrations) equal to or above the reporting limit were considered detections. All concentrations in fish tissue were reported from the laboratory in wet weights, with the exception of NAWQA trace-element data, which were converted from dry to wet weights $(\mu \mathrm{g} / \mathrm{g})$ to simplify data comparisons. All sediment concentrations were reported in dry weights $(\mathrm{mg} / \mathrm{kg})$. In this report, total dichlorodiphenyltrichloroethane (DDT) consists of the sum of concentrations of $o, p^{\prime}$-DDT, $p, p^{\prime}$-DDT, $o, p^{\prime}$-DDD, $p, p^{\prime}-$ DDD, $o, p^{\prime}$-DDE, and $p, p^{\prime}$-DDE. Total chlordane is defined as the sum of concentrations of cis-chlordane, transchlordane, cis-nonachlor, trans-nonachlor, and oxychlordane. Polychlorinated biphenyls consist of 209 synthetic chlorinated aromatic hydrocarbons. Total PCB concentration, as reported by the NWQL, is the sum of three common industrial mixes found in the United States: Aroclors 1242, 1254, and 1260 (Dennis J. Markovchick, National Water Quality Laboratory, written commun., 2001). For consistency, OEPA and IDEM data for these three types of Aroclors were summed and reported as total PCBs.

MIAM, national NAWQA, and IDEM samples were collected at one point in time at a single location. OEPA samples were also collected from a single location but at some locations samples may have been collected twice during 1990-98. Only the most recent sample collected was considered for analyses. For state-agency data, the number of samples may vary per compound analyzed.

\section{Standards and guidelines}

Contaminant concentrations measured in sediment and tissue discussed in this report were compared to sedimentquality guidelines and fish-tissue guidelines to identify areas and contaminants of concern with respect to their potential harmful effects on the aquatic biota. Guidelines are important tools for maintaining sediment quality, protecting benthic organisms, and identifying areas in need of restoration (Canadian Council of Ministers of the Environment, 1999). There are currently no sediment-quality criteria for the protection of benthic organisms in the United States; therefore, NAWQA-recommended Canadian guidelines were used for comparisons (U.S. Geological Survey, 2001) (table 4). The Canadian Interim Sediment Quality Guidelines (ISQG) were used to evaluate the sediment quality for SOCs and trace elements (Canadian Council of Ministers of the Environment, 1999). These guidelines consist 
Table 4. Canadian Sediment Quality Guidelines and New York Fish Flesh Criteria for trace elements, organochlorine insecticides, total polychlorinated biphenyls, and semivolatile organic compounds including common sources, uses, and examples of potential adverse effects to wildlife

[--, not available; PEL, Probable Effect Level; TEL, Threshold Effect Level; ug/g, micrograms per gram; $\mu \mathrm{g} / \mathrm{kg}$, micrograms per kilogram ]

\begin{tabular}{lcccc}
\hline $\begin{array}{c}\text { Trace element or } \\
\text { organic compound }\end{array}$ & $\begin{array}{c}\text { Canadian Sediment } \\
\text { Quality Guidelines }\end{array}$ & $\begin{array}{c}\text { New York Fish } \\
\text { Flesh Criteria }\end{array}$ & Common sources or uses & $\begin{array}{l}\text { Examples of potential } \\
\text { adverse effects to fish }\end{array}$
\end{tabular}

\section{Trace elements $(\mu \mathrm{g} / \mathrm{g})$}

\begin{tabular}{|c|c|c|c|c|c|}
\hline Arsenic & 5.9 & 17.0 & - & $\begin{array}{l}\text { Orchard and forest sprays, wood preservative, } \\
\text { herbicides, pesticides, glass and textile } \\
\text { manufacuring, animal-feed additives (Rheaume } \\
\text { and others, 2000; Agency for Toxic Substances } \\
\text { and Disease Registry, 2001c). }\end{array}$ & $\begin{array}{l}\text { Increased production of } \\
\text { mucus causing suffocation, } \\
\text { damage to gill epithelium } \\
\text { (Irwin and others, 1997). }\end{array}$ \\
\hline Cadmium & 0.6 & 3.5 & -- & $\begin{array}{l}\text { Batteries, plastics, sludge disposal, metal coatings } \\
\text { (Rheaume and others, 2000; Agency for Toxic } \\
\text { Substances and Disease Registry, 2001b). }\end{array}$ & $\begin{array}{l}\text { Behavioral, growth, and } \\
\text { physiological problems } \\
\text { (Irwin and others, 1997). }\end{array}$ \\
\hline Chromium & 37.3 & 90.0 & -- & $\begin{array}{l}\text { Chrome plating, leather tanning, wood preserving, } \\
\text { photocopying machines, steel and glass } \\
\text { manufacturing (Agency for Toxic Substances and } \\
\text { Disease Registry, 2001b; U.S. Department of } \\
\text { Energy, 2002). }\end{array}$ & $\begin{array}{l}\text { Decreased weight gain, } \\
\text { impaired reproduction } \\
\text { (Irwin and others, 1997). }\end{array}$ \\
\hline Copper & 35.7 & 197.0 & -- & $\begin{array}{l}\text { Plumbing; fungicides and algal control; production } \\
\text { of wire, metal, pipes and pennies; treatment for } \\
\text { plant diseases; water treatment; wood, leather and } \\
\text { fabric preservative (Rheaume and others, 2000; } \\
\text { Agency for Toxic Substances and Disease } \\
\text { Registry, 200lb). }\end{array}$ & $\begin{array}{l}\text { Altered migratory and other } \\
\text { behaviors; fathead minnow } \\
\text { embryos hatch at earlier } \\
\text { stages of development } \\
\text { (Irwin and others, 1997). }\end{array}$ \\
\hline Lead & 35.0 & 91.3 & -- & $\begin{array}{l}\text { Batteries, radiation protection for televisions and } \\
\text { computers, circuit boards in computers and other } \\
\text { electronic equipment, optical and nuclear medical } \\
\text { technology, steel and glass manufacturing } \\
\text { (Rheaume and others, 2000; Agency for Toxic } \\
\text { Substances and Disease Registry, 2001b; U.S. } \\
\text { Department of Energy, 2002). }\end{array}$ & $\begin{array}{l}\text { Formation of excess mucus } \\
\text { that can coat the gills and } \\
\text { cause respiratory problems } \\
\text { (Irwin and others, 1997). }\end{array}$ \\
\hline Mercury & 0.17 & 0.486 & -- & $\begin{array}{l}\text { Batteries, paint, coal and waste combustion, } \\
\text { thermometers, dental fillings, steel and glass } \\
\text { manufacturing (Rheaume and others, 2000; } \\
\text { Agency for Toxic Substances and Disease } \\
\text { Registry, 2001b; U.S. Department of Energy, } \\
\text { 2002). }\end{array}$ & $\begin{array}{l}\text { Reduced reproductive } \\
\text { success, impaired growth, } \\
\text { and developmental and } \\
\text { behavioral abnormalities } \\
\text { (Eisler, 1985-99). }\end{array}$ \\
\hline Zinc & 123 & 315 & -- & $\begin{array}{l}\text { Production of alloys and brass in steel and iron } \\
\text { products, road-surface runoff, agricultural } \\
\text { erosion, domestic and trial sewage, printing } \\
\text { plates, dye manufacture, cosmetics, } \\
\text { pharmaceuticals, pesticides, fertilizers (Rheaume } \\
\text { and others, 2000). }\end{array}$ & $\begin{array}{l}\text { Destruction of gill } \\
\text { epithelium and consequent } \\
\text { tissue hypoxia (Eisler, } \\
\text { 1985-99). }\end{array}$ \\
\hline
\end{tabular}

Synthetic organic compounds

\begin{tabular}{|c|c|c|c|c|c|}
\hline \multicolumn{6}{|c|}{ Organochlorine insecticides and polychlorinated biphenyls (PCBs) $(\mu \mathrm{g} / \mathrm{kg})$} \\
\hline Total chlordane & 4.5 & 8.87 & 500 & $\begin{array}{l}\text { Pesticide for homes, lawns, gardens, turf, corn, } \\
\text { potatoes, and tomatoes (Agency for Toxic } \\
\text { Substances and Disease Registry, 1994). }\end{array}$ & $\begin{array}{l}\text { Endrocrine distruption, liver } \\
\text { and kidney lesions, } \\
\text { increased respiration rate, } \\
\text { abnormal swimming } \\
\text { patterns, convuIsions, and } \\
\text { loss of equilibrium } \\
\text { (Nowell and others, 1999; } \\
\text { Eisler, 1985-99). }\end{array}$ \\
\hline
\end{tabular}


Table 4. Canadian Sediment Quality Guidelines and New York Fish Flesh Criteria for trace elements, organochlorine insecticides, total polychlorinated biphenyls, and semivolatile organic compounds including common sources, uses, and examples of potential adverse effects to wildlife-Continued

[--, not available; PEL, Probable Effect Level; TEL, Threshold Effect Level; ug/g, micrograms per gram; $\mu \mathrm{g} / \mathrm{kg}$, micrograms per kilogram ]

\begin{tabular}{|c|c|c|c|c|}
\hline \multirow{2}{*}{$\begin{array}{l}\text { Trace element or } \\
\text { organic compound }\end{array}$} & \multicolumn{2}{|c|}{$\begin{array}{l}\text { Canadian Sediment } \\
\text { Quality Guidelines }\end{array}$} & \multirow{2}{*}{$\begin{array}{l}\text { New York Fish } \\
\text { Flesh Criteria }\end{array}$} & \multirow[t]{2}{*}{ Common sources or uses } \\
\hline & TEL & PEL & & \\
\hline DDD & 3.54 & 8.51 & -- & Metabolite of DDT. \\
\hline DDE & 1.42 & 6.75 & -- & Metabolite of DDT. \\
\hline DDT & 1.19 & 4.77 & 200 (total DDT) & Insecticide (Rheaume and others, 2000). \\
\hline Dieldrin & 2.85 & 6.67 & 120 & $\begin{array}{l}\text { Insecticide primarily for corn and citrus, sheep dips, } \\
\text { treatment of wood, mothproofing woolen goods, } \\
\text { public health control of mosquitoes and tsetse } \\
\text { flies (Department of Health and Human Services, } \\
\text { 2002; Larson and others, 1999; Agency for Toxic } \\
\text { Substances and Disease Registry, 1993). }\end{array}$ \\
\hline Endrin & 2.67 & 62.4 & 25 & $\begin{array}{l}\text { Insecticide on field crops such as cotton and grains, } \\
\text { control of rodents and birds (Environmental } \\
\text { Media Services, 2002). }\end{array}$ \\
\hline gamma-HCH & 0.94 & 1.38 & 100 (total $\mathrm{HCH}$ ) & $\begin{array}{l}\text { Treatment of wood-inhabiting beetles and seeds, } \\
\text { flea and lice dip, soil treatment; used in lotions, } \\
\text { creams, and shampoos for the control of lice and } \\
\text { mites in humans (U.S. environmental Protection } \\
\text { Agency, 2002c). }\end{array}$ \\
\hline
\end{tabular}

\begin{tabular}{|c|c|c|c|c|}
\hline Heptachlor epoxide & 0.60 & 2.74 & $\begin{array}{l}200 \\
\text { (total heptachlor) }\end{array}$ & Fire ant control in power transformers. \\
\hline Hexachlorobenzene & -- & -- & 330 & $\begin{array}{l}\text { Used in manufacture of chemicals used as solvents, } \\
\text { other chlorine-containing compounds, and } \\
\text { pesticides, in combustion processes such as } \\
\text { burning of city wastes, produced as a byproduct } \\
\text { in waste streams of chlor-alkali and wood } \\
\text { preserving plants (Agency for Toxic Substance } \\
\text { and Disease Registry, 1997). }\end{array}$ \\
\hline Mirex & -- & -- & 330 & $\begin{array}{l}\text { Control of fire ants, flame retardant in plastics, } \\
\text { rubber, paint, paper, and electrical goods (Agency } \\
\text { for Toxic Substance and Disease Registry, 1996). }\end{array}$ \\
\hline Total PCBs & 34.1 & 277 & 110 & $\begin{array}{l}\text { Used in adhesives, inks, carbonless duplicating } \\
\text { paper, and as coolants for capacitors and } \\
\text { transformers (Eisler, 1985-99; Agency for Toxic } \\
\text { Substance and Disease Registry, 2001a; U.S. } \\
\text { Environmental Protection Agency, 2001). }\end{array}$ \\
\hline
\end{tabular}

Examples of potential adverse effects to fish
Endrocrine disruption, liver and kidney lesions (Nowell and others, 1999).

Endrocrine disruption, liver and kidney lesions (Nowell and others, 1999).

Endrocrine disruption, liver and kidney lesions (Nowell and others, 1999).

Endrocrine disruption, liver and kidney lesions (Nowell and others, 1999).

Highly toxic to fish. (Environmental Media Services, 2002).

Highly to very highly toxic (Extoxnet, 2001).

Very highly toxic to most fish species (Extoxnet, 2001).

Slightly toxic (Extoxnet, 2001).

Known endocrine disruptors, reproductive failure, birth defects, skin lesions, tumors, and liver disorders (Eisler, 1985-99).

Semivolatile organic compounds (SVOCs) $(\mu \mathrm{g} / \mathrm{kg})$

\begin{tabular}{|c|c|c|c|c|}
\hline Acenaphthene & 6.71 & 88.9 & -- & $\begin{array}{l}\text { Used in dyes, plastics, insecticides and fungicides } \\
\text { (Irwin and others, 1997). }\end{array}$ \\
\hline Acenaphthylene & 5.87 & 128 & -- & $\begin{array}{l}\text { Coal and tar products, product of combustion } \\
\text { (Irwin and others, 1997). }\end{array}$ \\
\hline Anthracene & 46.9 & 245 & -- & $\begin{array}{l}\text { Exhaust from motor vehicles; cigarette, marijuana } \\
\text { and cigar smoke; emissions from coal-, oil-, and } \\
\text { wood-burning stoves, furnaces, and power plants } \\
\text { (Irwin and others, 1997). }\end{array}$ \\
\hline
\end{tabular}


Table 4. Canadian Sediment Quality Guidelines and New York Fish Flesh Criteria for trace elements, organochlorine insecticides, total polychlorinated biphenyls, and semivolatile organic compounds including common sources, uses, and examples of potential adverse effects to wildlife-Continued

[--, not available; PEL, Probable Effect Level; TEL, Threshold Effect Level; ug/g, micrograms per gram; $\mu \mathrm{g} / \mathrm{kg}$, micrograms per kilogram ]

\begin{tabular}{|c|c|c|c|c|c|}
\hline \multirow{2}{*}{$\begin{array}{l}\text { Trace element or } \\
\text { organic compound }\end{array}$} & \multicolumn{2}{|c|}{$\begin{array}{l}\text { Canadian Sediment } \\
\text { Quality Guidelines }\end{array}$} & \multirow{2}{*}{$\begin{array}{l}\text { New York Fish } \\
\text { Flesh Criteria }\end{array}$} & \multirow[t]{2}{*}{ Common sources or uses } & \multirow{2}{*}{$\begin{array}{l}\text { Examples of potential } \\
\text { adverse effects to fish }\end{array}$} \\
\hline & TEL & PEL & & & \\
\hline Benz $[a]$ anthracene & 31.7 & 385 & $\overline{--}$ & $\begin{array}{l}\text { Engine exhaust, cigarette smoke, colal-tar pitch, } \\
\text { coke oven emissions (Irwin and others, 1997). }\end{array}$ & -- \\
\hline Benzo $[a]$ pyrene & 31.9 & 782 & -- & $\begin{array}{l}\text { Crude oils and coal tars; used in furnace blacks, } \\
\text { automobile tires, and rubber stoppers (Irwin and } \\
\text { others, 1997). }\end{array}$ & -- \\
\hline Chrysene & 57.1 & 862 & -- & $\begin{array}{l}\text { Coal tar, exhaust from motor vehicles and other } \\
\text { gasoline and diesel engines, emission from coal-, } \\
\text { oil-, and wood-burning stoves and furnaces, } \\
\text { cigarette smoke (Irwin and others, 1997). }\end{array}$ & -- \\
\hline $\operatorname{Dibenz}[a, h]$ anthracene & 6.22 & 135 & -- & $\begin{array}{l}\text { Product of incomplete combustion, forest fires } \\
\text { (Irwin and others, 1997). }\end{array}$ & -- \\
\hline Fluoranthene & 111 & 2355 & - & $\begin{array}{l}\text { Exhaust from gasoline engines, coal tar, coke ovens, } \\
\text { crude oil (Irwin and others, 1997). }\end{array}$ & $\begin{array}{l}\text { A co-carcinogen (a chemical } \\
\text { that is noncarcinogenic, } \\
\text { "but when present with } \\
\text { another carcinogen, will } \\
\text { enhance that chemical's } \\
\text { carcinogenicity") (Irwin } \\
\text { and others, 1997). }\end{array}$ \\
\hline $9 H$ Fluorene & 21.2 & 144 & -- & $\begin{array}{l}\text { Product of incomplete combustion, cigarette smoke, } \\
\text { exhaust from gasoline engines (Irwin and others, } \\
\text { 1997). }\end{array}$ & -- \\
\hline 2-Methylnaphthalene & 20.2 & 201 & - & -- & -- \\
\hline Naphthalene & 34.6 & 391 & -- & $\begin{array}{l}\text { Used in petroleum products and byproducts, jet } \\
\text { fuels (Irwin and others, 1997). }\end{array}$ & -- \\
\hline Phenanthrene & 41.9 & 515 & -- & $\begin{array}{l}\text { Product of incomplete combustion of fossil fuels } \\
\text { and wood, auto emissions, steel manufacturing, } \\
\text { and foundries (U.S. Department of Energy, } \\
\text { 2002). }\end{array}$ & -- \\
\hline Pyrene & 53.0 & 875 & -- & $\begin{array}{l}\text { Product of incomplete combustion, exhaust from } \\
\text { gasoline and diesel engines (Irwin and others, } \\
\text { 1997). }\end{array}$ & -- \\
\hline Diethylphthalate & -- & -- & -- & $\begin{array}{l}\text { Commonly used as a plasticizer, in insecticide } \\
\text { sprays, and the manufacture of perfume } \\
\text { compounds and varnishes (National Institute of } \\
\text { Health Sciences, 2002). }\end{array}$ & -- \\
\hline 2,6-Dinitrotoluene & -- & -- & -- & $\begin{array}{l}\text { Commonly used in the manufacturing of } \\
\text { polyurethane, as a component of explosives and } \\
\text { automobile airbags, and in dye prodesses (U.S. } \\
\text { Department of Energy, 2002; Agency for Toxic } \\
\text { Substances and Disease Registry, 2001b). }\end{array}$ & -- \\
\hline$p$-Cresol & & & & $\begin{array}{l}\text { Automobile emissions, metal refining, and } \\
\text { manufacturing of chemicals and wood pulp (U.S. } \\
\text { Environmental Protection Agency, 2002c). }\end{array}$ & -- \\
\hline
\end{tabular}


of two effect values, the threshold effect level (TEL; also known as sediment-quality guideline, SQG), and the probable effect level (PEL). The TEL defines the concentration below which adverse effects are rarely anticipated, whereas the PEL defines the concentration above which adverse effects are frequently anticipated (Canadian Council of Ministers of the Environment, 1999). NAWQA trace-element samples were based on analyses of the sieved $<63-\mu \mathrm{m}$ sediment fraction, where concentrations tend to be highest; therefore, comparisons with the Canadian guidelines, which were based on analyses of unsieved- sample data, may overestimate the effects of trace-element concentrations in sediments (Deacon and Stephens, 1998).

Generally, standards or guidelines for contaminant concentrations in fish tissue apply to edible portions of fish that are most likely to be consumed by humans. There are currently no published guidelines, standards, or aquatic criteria for trace-element concentrations in fish liver. Wholefish samples submitted for organic analyses were compared to New York Fish Flesh Criteria (NYFFC; Newell and others, 1987) for the protection of fish-eating wildlife.

\section{Sediment and fish-tissue quality}

Although direct comparisons of streambed sediment and fish-tissue data could not be made among the agencies, aggregation of state-agency data with MIAM data does allow for the display of areas of guideline exceedances within the study unit. Geographic distributions of sediment and tissue sites showing concentrations in exceedance of guidelines and (or) number of detections of trace elements in fish tissue are used to identify areas where wildlife health is of potential concern and where further investigations may be warranted. Currently, no health standards or aquatic criteria have been developed for trace elements in fish livers; therefore, the number of trace elements detected per sample location is shown. Only constituents with current guidelines are shown. Concentrations of other constituents may be atlevels that could have adverse biological effects, but guidelines have not yet been established. Percentages of sites where SOC and trace elements were detected are shown in figure 2 .
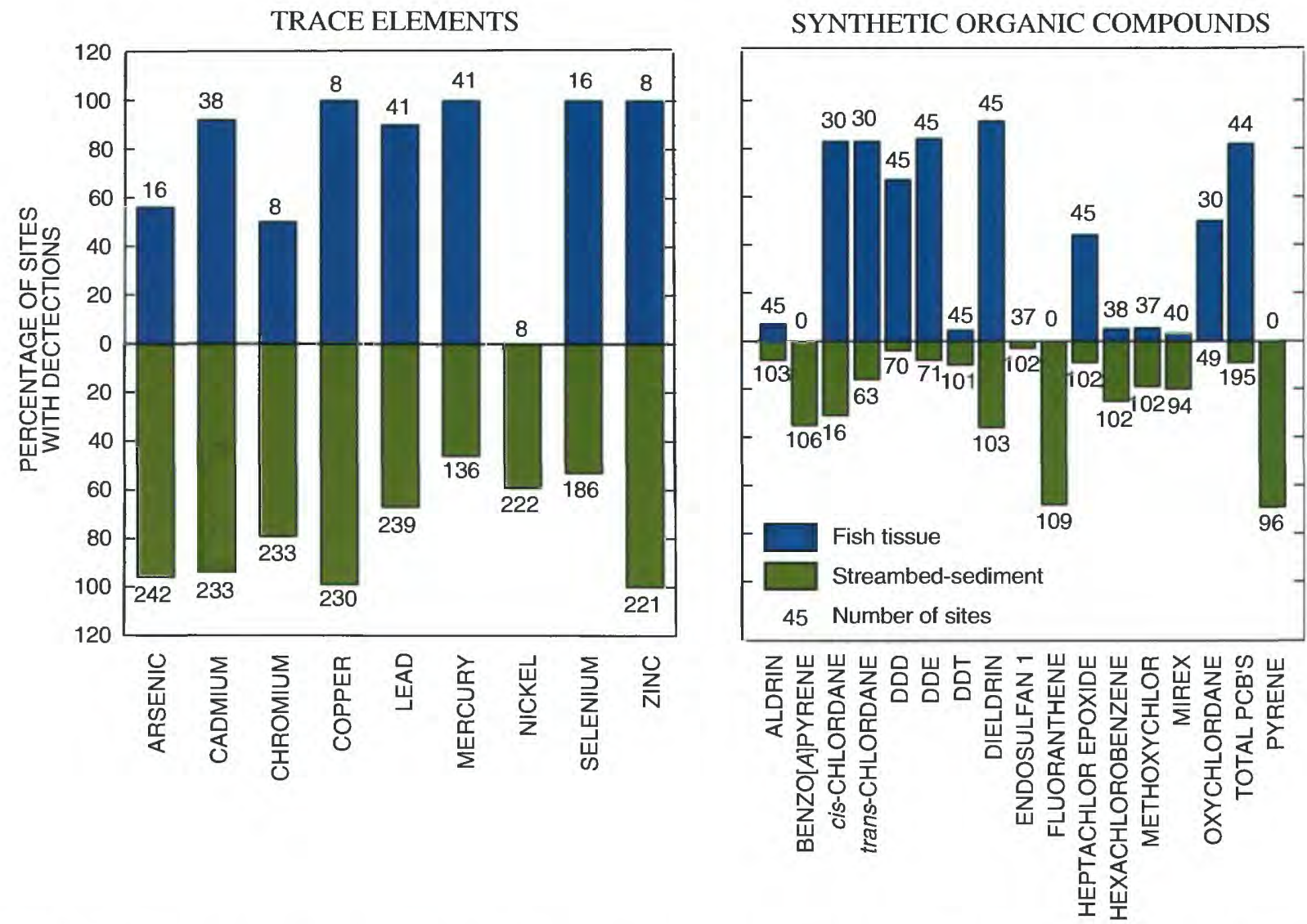

Figure 2. Percentage of sites where trace elements and synthetic organic compounds were detected within the Great and Little Miami River Basins, Ohio and Indiana, 1990-1998. (Fish-tissue data include U.S. Geological Survey, Ohio Environmental Protection Agency whole-fish and liver data only; streambed-sediment data include U.S. Geological Survey, Ohio Environmental Protection Agency, and Indiana Department of Environmental Management sites.) 
For each chemical group (trace elements, organochlorine insecticides, PCBs, and SVOCs) the occurrence and distribution in each media (streambed sediment and fish tissue) are discussed. A brief discussion of chemical uses and concerns is also presented. For each media type, results are described for MIAM sampling locations, national NAWQA data (when available), state-agency data, and constituents most frequently found. Samples for all data sets were predominantly from agricultural areas; therefore, an even distribution of sampling locations was not available, and the influence of land use on contaminant concentrations could not be accurately determined.

\section{Trace elements}

MIAM sediment and tissue samples were analyzed for 46 and 22 trace elements, respectively. Selected trace elements that have been classified by the U.S. Environmental Protection Agency (1999) as "priority pollutants" and are considered to be toxic to aquatic organisms-arsenic, cadmium, chromium, copper, lead, mercury, nickel, selenium, and zinc-are the focus of this paper.
Streambed sediment. Trace-element concentrations in sediments generally increase with decreasing sediment particle size (Shelton and Capel, 1994). Median sand, silt, and clay percentages among the MIAM sites were 93.1, 4.1, and 3.1, respectively. Particle-size distribution and organiccarbon concentrations at MIAM sampling sites are listed in table 5. State-agency particle-size distribution is discussed where data were available; however, organic-carbon data were not available for state-agency samples.

All nine trace elements of interest were detected at each MIAM sampling location. Cadmium, copper, and mercury concentrations were highest at the mixed-land-use site Great Miami River below Hamilton. Sediment samples from the urban site, Holes Creek, had the greatest concentrations of arsenic, nickel, and chromium. The second highest concentrations of zinc, arsenic, copper, nickel, and cadmium were detected at the agricultural site Great Miami River at Tipp City. The percentages of silt and clay at these sites were higher than the median percentages for the overall MIAM data set (table 5), so the higher proportion of fineparticles may contribute to the higher concentrations of trace elements at these sites. No PELs were exceeded; however, TELs were exceeded for arsenic and chromium

Table 5. Particle-size distribution and organic-carbon concentrations at MIAM streambed-sediment sampling sites, Ohio and Indiana, 1998

[mm, millimeters: $\mu \mathrm{m}$, micrometers]

\begin{tabular}{|c|c|c|c|c|}
\hline \multirow[b]{2}{*}{ Station name } & \multicolumn{3}{|c|}{ Percentage in streambed sediment } & \multirow{2}{*}{$\begin{array}{c}\text { Organic } \\
\text { carbon, } \\
\text { (<63 } \mu \mathrm{m} \text { dry } \\
\text { weight, } \\
\text { percent) }\end{array}$} \\
\hline & $\begin{array}{c}\text { Sand } \\
(<2 \mathrm{~mm} \text { and } \\
>0.062 \mathrm{~mm})\end{array}$ & $\begin{array}{c}\text { Silt } \\
(<0.062 \mathrm{~mm} \\
\text { and } \\
>0.004 \mathrm{~mm})\end{array}$ & $\begin{array}{c}\text { Clay } \\
(<0.004 \mathrm{~mm})\end{array}$ & \\
\hline Holes Creek at Kettering, Ohio & 88.8 & 5.0 & 6.2 & 1.11 \\
\hline Whitewater River near Nulltown, Indiana & 94.7 & 3.8 & 1.5 & 1.79 \\
\hline $\begin{array}{l}\text { Stillwater River on Old Springfield Rd near } \\
\text { Union, Ohio }\end{array}$ & 95.8 & 1.6 & 2.6 & 2.62 \\
\hline Great Miami River near Tipp City, Ohio & 91.5 & 4.4 & 4.1 & 2.38 \\
\hline Mad River near Hwy 41 near Springfield, Ohio & 82.4 & 11.3 & 6.3 & 2.14 \\
\hline $\begin{array}{l}\text { East Fork Little Miami River near } \\
\text { Williamsburg, Ohio }\end{array}$ & 98.5 & 0.9 & 0.6 & 1.49 \\
\hline Little Miami River at Milford, Ohio & 97.2 & 1.6 & 1.2 & 2.20 \\
\hline Great Miami River below Hamilton, Ohio & 90.7 & 5.7 & 3.6 & 2.32 \\
\hline Median & 93.1 & 4.1 & 3.1 & 2.2 \\
\hline Mean & 92.5 & 4.3 & 3.3 & 2.0 \\
\hline
\end{tabular}




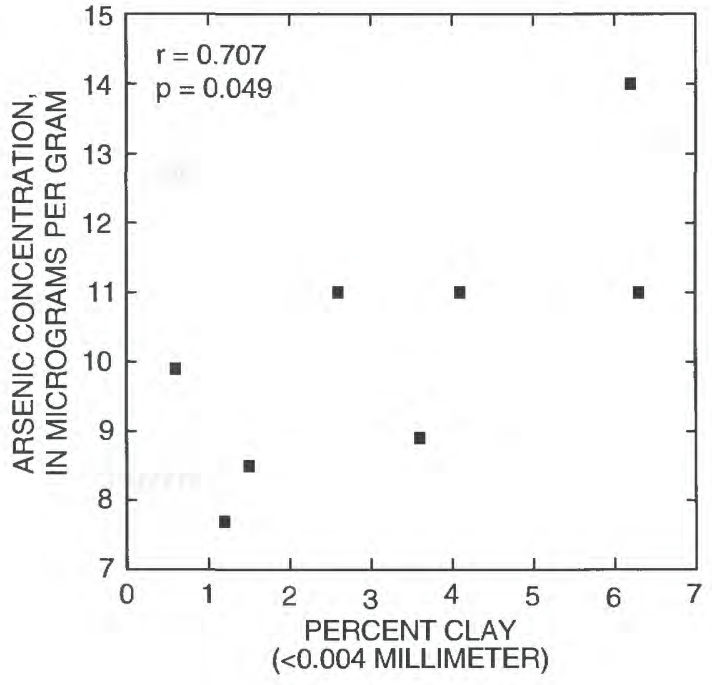

Figure 3. Arsenic concentrations as a function of sediment clay content at the Great and Little Miami River Basin study unit sampling locations, Ohio and Indiana, 1998.

concentrations at all MIAM sites and at one or more sites for zinc (five sites), cadmium (two sites), and lead (one site). Arsenic has a tendency to adsorb to sediments, especially clay particles (Irwin and others, 1997). This was seen at the MIAM sites where increased arsenic was found with increasing clay content ( $r h o=0.707, p=0.049$ ) (fig. 3 ).

Concentrations of zinc in sediment were highest at two agricultural sites, East Fork Little Miami River $(160 \mu \mathrm{g} / \mathrm{g})$ and Great Miami River at Tipp City $(150 \mu \mathrm{g} / \mathrm{g})$. Lead concentrations at MIAM sites were greatest and exceeded the TEL of $35 \mu \mathrm{g} / \mathrm{g}$ at the two mixed-land-use sites, Little Miami River ( $38 \mu \mathrm{g} / \mathrm{g})$ and Great Miami River at Hamilton $(36 \mu \mathrm{g} / \mathrm{g})$. Clay and silt percentages and organiccarbon concentrations at these sites were higher than the MIAM medians (table 5) and are potential factors contributing to elevated lead concentrations at these sites.

MIAM sediment data were compared with national NAWQA trace-element data collected as part of studies beginning 1991 and 1994 (fig. 4). The national median concentrations of the trace elements were calculated from the results of Wentz (1999). All MIAM sites exceeded the national NAWQA median for arsenic. Concentrations were higher than the median for copper and nickel ( 6 sites), zinc (5), selenium and mercury (4), lead and cadmium (3), and chromium (1).

For state-agency data, the most commonly detected elements were zinc, copper, arsenic, cadmium, chromium, lead, nickel, selenium, and mercury $(100,99,96,94,78,65$, 57,49 , and 42 percent of sites, respectively). PEL guidelines for one or more trace elements were exceeded at 32 sites (fig. 5). Zinc and lead concentrations exceeded PELs most often. Zinc was detected at all 213 state-agency sites. Concentrations exceeded PELs at 16 sites (7.5 percent), 5 of which were on Dicks Creek downstream from Middletown. Of the 231 state-agency sites analyzed for lead, concentrations were detected at 151 sites ( 65 percent), and 15 concentrations (6.5 percent) exceeded the PEL. Lead was the only trace element to exceed a PEL in the Whitewater River Basin; it was detected at $99.3 \mu \mathrm{g} / \mathrm{g}$ at the East Fork Whitewater River below Richmond. Arsenic concentrations exceeded TELs most often. Of 234 state-agency sites, 105 exceeded TELs ( 45 percent); 60 exceedances were in the Great Miami River Basin and 45 in the Little Miami River Basin, 5 of which were from Turtle Creek, a Little Miami tributary. Particle size was not an important factor influencing concentrations of lead or zinc in the study unit, but it could be affecting arsenic concentrations. No statistically significant correlation (Spearman) was found between lead or zinc and particle-size distribution; however, a correlation was found between arsenic concentrations and percentage of silt $(\mathrm{rho}=0.49, \mathrm{p}=<0.0001)$ and clay $(\mathrm{rho}=0.28, \mathrm{p}=$ $0.0003)$. PEL were also exceeded for concentrations of arsenic (5 sites), cadmium (5 sites), chromium ( 3 sites), and mercury (1 site).

Areas of elevated trace-element concentrations in the study unit include selected reaches of the Great Miami River tributaries Mad River near Springfield and Dicks Creek, the Upper Great Miami River main stem near Troy, and the Little Miami River at river mile (RM) 50.75. Dicks Creek had the most trace-element PEL exceedances (five) of all tributaries. On the main stem, the Great Miami River site at (RM) 51.3 had the greatest number of PEL exceedances with six (arsenic, cadmium, chromium, lead, mercury, and zinc) followed by Little Miami at RM 50.75 with three (arsenic, cadmium, and lead). Of the 32 sites where sediment exceedances were detected, 21 ( 66 percent) were in the Great Miami River Basin and 17 (53 percent) of these were from tributaries. A higher frequency of exceedances was found in the Great Miami River Basin (21 of 110 sites, 19 percent exceedance) than in the Little Miami River Basin (11 of 126 sites, 8.7 percent exceedance).

Fish tissue. Arsenic, cadmium, copper, mercury, selenium, and zinc were detected in fish tissue samples collected at all MIAM sites. The highest concentrations of copper $(42.3 \mu \mathrm{g} / \mathrm{g})$ and zinc $(279 \mu \mathrm{g} / \mathrm{g})$ were in tissue samples from the urban site, Holes Creek. Samples from the agricultural site Stillwater River had the highest concentrations of arsenic $(0.35 \mu \mathrm{g} / \mathrm{g})$ and mercury $(0.09 \mu \mathrm{g} / \mathrm{g})$. Cadmium was highest at the Great Miami River at Hamilton $(12.1 \mu \mathrm{g} / \mathrm{g})$ and Stillwater River $(12.0 \mu \mathrm{g} / \mathrm{g})$ sites. Lead was detected at all MIAM sites with the exception of Mad River. According to Irwin (1997), concentrations of lead in fish tissue tend to increase with increasing fish age. MIAM age data showed 


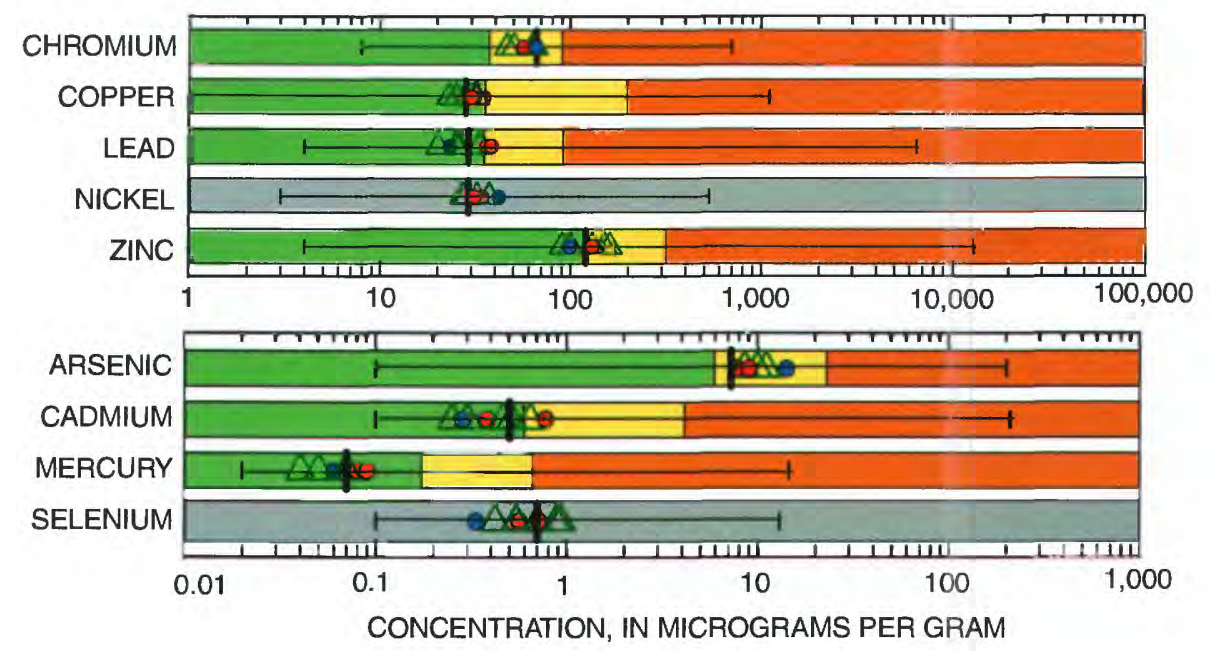

\section{EXPLANATION}

BED-SEDIMENT-QUALITY GUIDELINES

Less than Threshold Effect Level (TEL)

Greater than TEL and less that Probable Effect Level (PEL)

Greater than PEL

No guidelines

\section{SUMMARY STATISTICS}

$\longmapsto \quad$ NAWQA composite range

I NAWQA composite median

$\begin{array}{ll} & \text { SAMPLING SITE } \\ \triangle & \text { Agriculture } \\ \text { - Urban } \\ \text { Mixed }\end{array}$

Figure 4. Concentrations of selected trace elements at Great and Little Miami River sites compared to Canadian Sediment-Quality Guidelines and selected 1991 and 1994 national NAWQA study units.

no correlation between fish age and lead concentrations (rho $=0.48, p=0.23$ ). Summaries of national NAWQA data for trace elements in tissue were not available. Results of a national assessment of mercury contamination at 21 study units, including the MIAM, are summarized in Appendix A.

State-agency data were available for mercury, lead, selenium, cadmium, and arsenic. Mercury (at 33 of 33 sites) and cadmium (at 27 of 30 sites) were detected most often, followed by lead (at 27 of 33 sites). Concentrations of mercury and lead were highest on the main stem Little Miami River, RM 83.1 and RM 64.2, $(0.274 \mu \mathrm{g} / \mathrm{g}$ and $1.88 \mu \mathrm{g} / \mathrm{g}$, respectively). Six of the seven highest concentrations of mercury were found in samples from three sites on the Little Miami River main stem between RM 18.5 and 38.6 and at three sites on the Stillwater River between RM 12.1 and 15.4. Cadmium was detected at 27 of 30 state-agency sites ( 90 percent). Lead was detected at 29 of 33 ( 88 percent) of the state-agency sites. The highest concentration of lead $(1.18 \mu \mathrm{g} / \mathrm{g})$ was detected at Little Miami River RM 64.2.
Four of the six highest lead concentrations were detected on the Great Miami River main stem; three were in Miami County within RM 114 and 95 in the upper Great Miami River. Of the samples with trace-element detections, 3 or more metals were detected at 27 Great Miami River Basin sites (76 percent). Detections of trace elements were most frequent on the Mad River near Springfield; on the Great Miami River main stem in the vicinity of Middletown, Hamilton, and north of Dayton; and along the main stem of the Little Miami River.

Possible sources of trace elements in sediment and tissue. Zinc, lead, and arsenic were detected more frequently at elevated concentrations than the other metals of interest. Zinc was the most commonly detected trace element in sediment, and more guideline exceedances were found for zinc than for any other element. Both urban and agricultural land uses are possible contributors of zinc in the study unit. Several industries in the area generate zinc wastes from plating, polishing, and metal-coating processes. 


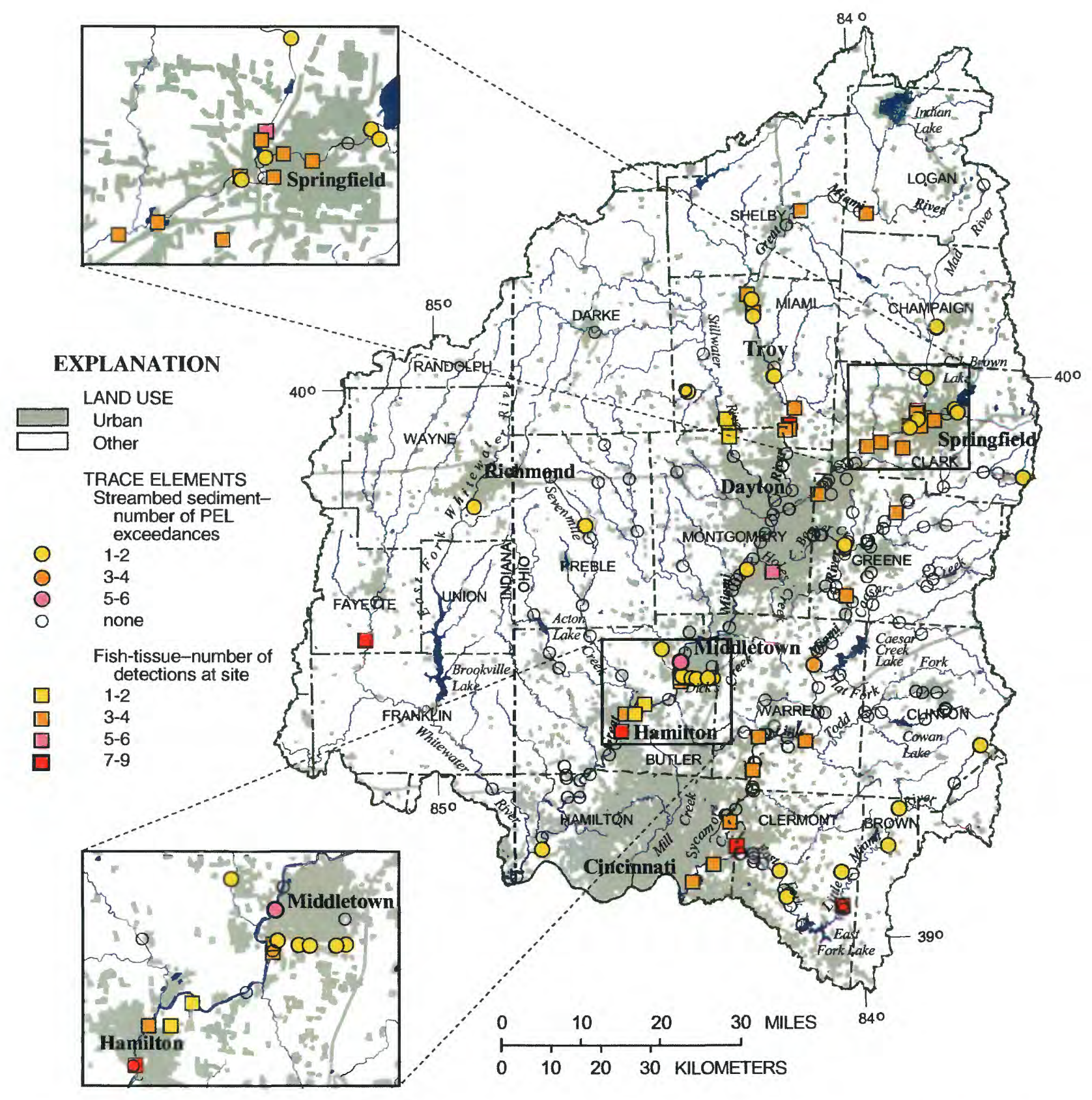

Figure 5. Location of streambed-sediment samples exceeding Canadian Sediment-Quality Guideline Probable Effect Levels (PELs) and trace-element detections in fish-tissue samples in the Great and Little Miami River Basins, Ohio and Indiana, 1990-98. 
Motor-vehicle part production and steel mills are the most common contributors of zinc-containing generated waste in the study unit (U.S. Environmental Protection Agency, $2002 b$ ). Industrial land use in Miami County also may contribute to elevated trace-element concentrations in this area. According to Toxic Release Inventory (TRI) data, industries in Miami County are significant contributors of trace-element waste, particularly zinc and lead, released onsite and offsite in the study unit (U.S. Environmental Protection Agency, 2002b). PEL exceedances for zinc concentrations were found at sites on Dicks Creek, which receives treated effluent from steel-manufacturing facilities in Butler County (Ohio Environmental Protection Agency, 1997a). Zinc was detected at all MIAM fish-tissue sites. Low concentrations of zinc are necessary for fish metabolism (Eisler, 1985-99). Physical conditions that increase zinc bioavailability (low pH, alkalinity, dissolved oxygen, and high temperatures) (Eisler, 1985-99) are not found in most surface waters in the MIAM study unit.

Lead guidelines for sediment were exceeded more often than those for any other element with the exception of zinc. Large sources of lead in the study unit are steel mills and blast furnaces, motor vehicle part production, and electronics manufacturing (U.S. Environmental Protection Agency, 2002b). Elevated concentrations of lead in fish tissue were detected between RM 114 and RM 95 in the Upper Great Miami River and are likely related to industrial land use in Miami County. 'Five Comprehensive Environmental Response Compensation and Liability Information System ${ }^{1}$ (CERCLIS) sites are upstream near the city of Troy; two of these, an incinerator and lead-battery reclamation facility, are National Priority List (NPL) sites (U.S. Environmental Protection Agency, 2002a). Lead may enter surface water from atmospheric fallout, runoff, or wastewater. Once in the water column, lead adsorbs to organic matter and clay minerals (Irwin and others, 1997). No correlation was found between lead concentrations and clay distribution in the study unit. Lead, which has no known essential biological function, is highly toxic to fish, particularly at early life stages (Irwin and others, 1997). Increasing fish age, a possible factor contributing to increased lead concentrations, did not correlate with elevated lead concentrations in fish tissue at the MIAM sampling sites.

Arsenic concentrations exceeded more sediment TELs than did concentrations of any other trace element in the study unit. Arsenic adsorbs from water to sediments, especially clays (Irwin and others, 1997). Arsenic concentrations at state-agency sites slightly increased with percent clay and silt; therefore, particle-size distribution may be one factor affecting arsenic concentrations in the study unit. The

1 CERCLIS database contains general information on Superfund sites in the United States and its territories, including location, status, and actions taken. majority of arsenic exceedances were in the Great Miami River Basin, where streambeds consisting mostly of silt are found at 36 percent of the sample sites. Possible point sources of arsenic in the study unit are NPL sites including an incinerator, landfills, and an industrial-chemical waste transfer, disposal, and storage facility. Agricultural land use and feedlots, which are common in the study unit, also are possible sources; certain arsenicals have been used with chickens to increase egg production and with swine to increase rate of weight gain and to control dysentery (Irwin and others, 1997).

\section{Synthetic organic compounds}

For the purpose of this report, synthetic organic compounds (SOCs) include organochlorine insecticides, polychlorinated biphenyls (PCBs), and other semivolatile organic compounds (SVOCs). Each of these organic compounds is discussed individually in the following sections.

Synthetic organic compounds were not normalized for carbon content because of the low number of detections, and total organic carbon concentrations were not quantified for most of the non-USGS data. Spearman correlation coefficients were calculated to determine whether tissue concentrations correlated with lipid content. Analyses for selected compounds (dichlorodiphenyldichloroethylene (DDE), $\mathrm{rho}=0.26 \mathrm{p}=0.15$; dieldrin, rho $=0.23, \mathrm{p}=0.30$ ) showed no significant correlation; therefore, organochlorine insecticide concentrations were not normalized for lipid content.

Organochlorine insecticides. MIAM sediment and tissue samples were analyzed for 31 and 27 organochlorine insecticides, respectively. Sixteen of these compounds are listed as Priority Pollutants by the USEPA (1999). Organochlorine insecticides are among the most persistent SOCs in the environment because of their low water solubility, tendency to sorb to suspended particles and sediments, and resistance to biotic degradation and metabolic breakdown (Rinella and others, 1999). Organochlorine insecticides may enter the aquatic environment from agricultural and urban sources through soil erosion, runoff, and precipitation. Most organochlorine insecticides are no longer used for agriculture in the United States, but they are still manufactured here for use in other countries.

Streambed Sediment. Few organochlorine insecticides were detected in streambed sediments collected at the MIAM sites. Of the 31 compounds analyzed, 5 compounds were detected: trans-nonachlor, heptachlor epoxide, cischlordane, trans-chlordane, and dieldrin. The highest concentrations of cis-chlordane and trans-chlordane were detected at the mixed-land-use site Great Miami River at Hamilton. The only insecticide to exceed a guideline was heptachlor epoxide; the concentration of $1.1 \mu \mathrm{g} / \mathrm{kg}$ detected at the urban site, Holes Creek, exceeded the TEL 


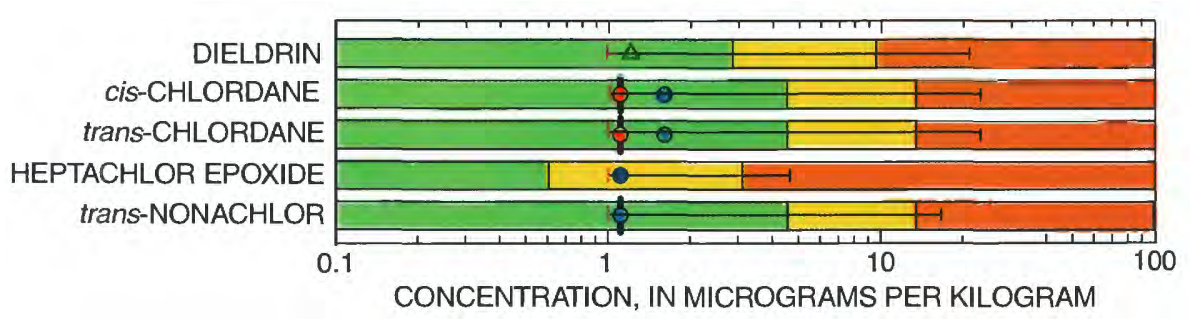

EXPLANATION

BED-SEDIMENT-QUALITY GUIDELINES

Less than Threshold Effect Level (TEL)

Greater than TEL and less than Probable Effect Level (PEL)

Greater than PEL

SUMMARY STATISTICS

NAWQA composite range

NAWQA composite median

NAWQA minimum concentration less than the detection limit

SAMPLING SITE

Agriculture

Urban

Mixed

Figure 6. Concentrations of selected organochlorine insecticides at MIAM streambed-sediment sites compared to Canadian SedimentQuality Guidelines and data from selected 1991 and 1994 national NAWOA study units. (National medians were below the minimum detection limit for all compounds at sites with mixed and agricultural land use. Medians at urban sites are shown where available.)

of $0.6 \mu \mathrm{g} / \mathrm{kg}$. Cis-chlordane, trans-chlordane, and transnonachlor also were detected at Holes Creek but at concentrations below the Canadian guidelines. MIAM organochlorine insecticide data were compared to national summary statistics computed for organochlorine pesticides in streambed sediment from 1991 and 1994 NAWQA study units (fig. 6). Cis- and trans-chlordane concentrations at Holes Creek $(1.6 \mu \mathrm{g} / \mathrm{kg})$ were higher than the median of $1.1 \mu \mathrm{g} / \mathrm{kg}$ for urban sites. All MIAM agricultural sites exceeded the national median for dieldrin $(<1 \mu \mathrm{g} / \mathrm{kg})$. Concentrations at the mixed-land-use site Great Miami River at Hamilton exceeded the national median for cis- and trans-chlordane $(<1 \mu \mathrm{g} / \mathrm{kg})$, heptachlor epoxide $(<1 \mu \mathrm{g} / \mathrm{kg})$, and trans-nonachlor $(<1 \mu \mathrm{g} / \mathrm{kg})$.

In state-agency data, the most commonly detected organochlorine insecticides were dieldrin, cis-chlordane, and hexachlorobenzene $(35,33$, and 24 percent of all sites, respectively). Organochlorine insecticide concentrations exceeded PELs at 25 of 184 sites (fig. 7). A higher frequency of PEL exceedances was found in the Great Miami River Basin (14 of 68 sites, 21 percent) than in the Little Miami River Basin (11 of 116 sites, 9 percent). PELs were exceeded for concentrations of dieldrin, total chlordane, lin- dane, heptachlor epoxide, DDT, and DDE. Concentrations of total chlordane exceeded the PEL at seven sites. Elevated total chlordane concentrations ranged from $10.9 \mu \mathrm{g} / \mathrm{kg}$ to $64 \mu \mathrm{g} / \mathrm{kg}$, the latter being found at the Great Miami River RM 0.16. Five of seven sites with elevated concentrations were from the Little Miami River Basin, and four of those five were from Little Beaver Creek, a tributary southeast of Dayton in Greene County. Concentrations of dieldrin exceeded PELs most often (12 sites), followed by total chlordane ( 8 sites), lindane (4 sites) DDT (2 sites) and heptachlor epoxide and DDE ( 1 site each). Of the 12 sites with dieldrin PEL exceedances, 9 were from the Great Miami River Basin. Sediment from the Great Miami River at RM 79.95 had the highest concentration $(67.0 \mu \mathrm{g} / \mathrm{kg})$, followed by sediment from the Great Miami River at RM 31.19 (60 $\mu \mathrm{g} / \mathrm{kg}$ ). Two sites, Little Miami River at Dolly Varden Road (RM 98.98) and Anderson Fork at Winchester Trail (RM 4.90), were the only sites to exceed PELs for dieldrin in the Little Miami Basin with concentrations of $16.6 \mu \mathrm{g} / \mathrm{kg}$ and $8.01 \mu \mathrm{g} / \mathrm{kg}$ respectively. Concentrations of dieldrin and heptachlor epoxide exceeded the most TELs (seven each), followed by lindane (four), DDE (three), and DDD and endrin 


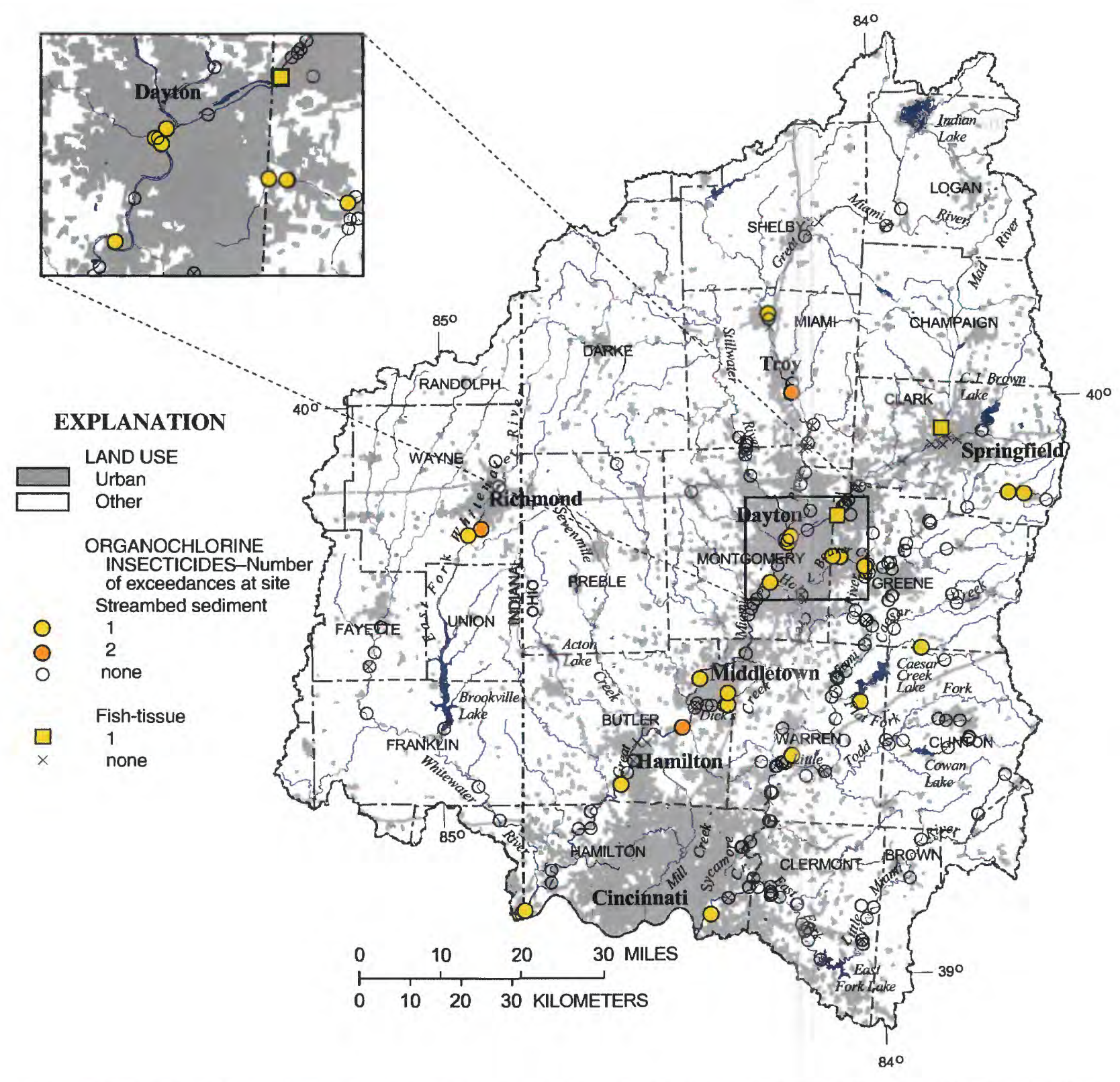

Figure 7. Location of streambed-sediment samples exceeding Canadian Sediment-Quality Guideline Probable Effect Levels (PELs) and fish tissue samples exceeding New York Fish Flesh Criteria (NYFFC) for organochlorine insecticides in the Great and Little Miami River Basins, Ohio and Indiana, 1990-98.

(one site each). Six of the seven dieldrin guideline exceedances were from the Little Miami River Basin, and six of seven heptachlor epoxide exceedances also were from the Little Miami River Basin.

Fish tissue. Of the 27 organochlorine insecticides analyzed, 11 were detected at MIAM fish-tissue sites. Dieldrin, DDE, trans-nonachlor, and cis-chlordane were detected at all eight sites. Concentrations of dacthal $(5 \mu \mathrm{g} / \mathrm{kg})$ and oxychlordane $(49 \mu \mathrm{g} / \mathrm{kg})$ were highest at the Great Miami River at Tipp City. The Mad River had the highest concentrations of cis-nonachlor $(40 \mu \mathrm{g} / \mathrm{kg})$, trans-nonachlor $(230$ $\mu \mathrm{g} / \mathrm{kg}), p, p^{\prime}-\mathrm{DDD}(31 \mu \mathrm{g} / \mathrm{kg}), p, p^{\prime}-\mathrm{DDE}(280 \mu \mathrm{g} / \mathrm{kg})$, cischlordane $(130 \mu \mathrm{g} / \mathrm{kg})$, and trans-chlordane $(45 \mu \mathrm{g} / \mathrm{kg})$. Total DDT (primarily DDE) in fish tissue at the Mad River was detected at a concentration $(311 \mu \mathrm{g} / \mathrm{kg})$ that exceeds the NYFFC guideline of $200 \mu \mathrm{g} / \mathrm{kg}$. Organochlorine insecticides detected at MIAM sites were compared to 1991 and 1994 national NAWQA summary statistics for agricultural, urban, and mixed-land-use settings (fig. 8). Mad River concentrations of cis- and trans-chlordane, cis and trans-nonachlor, exceeded national NAWQA maximum concentrations for agricultural sites. The concentration at 
Great Miami River at Hamilton exceeded the maximum concentration for hexachlorobenzene for mixed-land-use sites but was below NYFFC guidelines.

For state-agency data, the most commonly detected organochlorine insecticides in fish tissue were dieldrin, trans-chlordane, DDE, and cis-chlordane detected at 89, 82, 81 , and 77 percent of the sites, respectively. Four sites from the Little Miami River main stem had the highest concentrations of dieldrin $(45.2,50.5,68.7$, and $88.0 \mu \mathrm{g} / \mathrm{kg})$. The highest trans-chlordane concentrations were on the Great Miami River main stem downstream from Middletown and Dicks Creek (RM 48 and 47.5). The highest concentrations of DDE were measured at the Little Miami River RM 3.5 and RM $18.5(149 \mu \mathrm{g} / \mathrm{kg}$ and $101 \mu \mathrm{g} / \mathrm{kg})$ and Mad River RM 6.2 and $\mathrm{RM} 17.3(160 \mu \mathrm{g} / \mathrm{kg}$ and $100 \mu \mathrm{g} / \mathrm{kg})$. The most persistent metabolite of DDT is $p, p^{\prime}$-DDE, and the dominance of this metabolite may indicate that DDT is late in the degradation process and that no recent contamination has occurred. The Mad River had the eight highest cis-chlordane concentrations, five of which were on the main stem. The only NYFFC guideline exceeded was for the total DDT concentration at Mad River RM $6.2(203 \mu \mathrm{g} / \mathrm{kg})$.

Possible sources of organochlorine insecticides in sediment and tissue. In the study unit, dieldrin was the most commonly detected organochlorine in sediment and fish tissue, and concentrations exceeded the most sediment PELs. High dieldrin exceedances in the study unit are likely because of its persistence and widespread use in the past, especially in regions high in corn production. Approximately 84 percent of the farmland in the study unit is used for crop production, particularly corn, wheat, and soybeans (Debrewer and others, 2000). Dieldrin is a byproduct of the insecticide aldrin; therefore, elevated dieldrin concentrations in the study unit may reflect a combination of aldrin and dieldrin residues (Nowell, 1999). The second most commonly detected organochlorine insecticide in sediment, cis-chlordane, was the

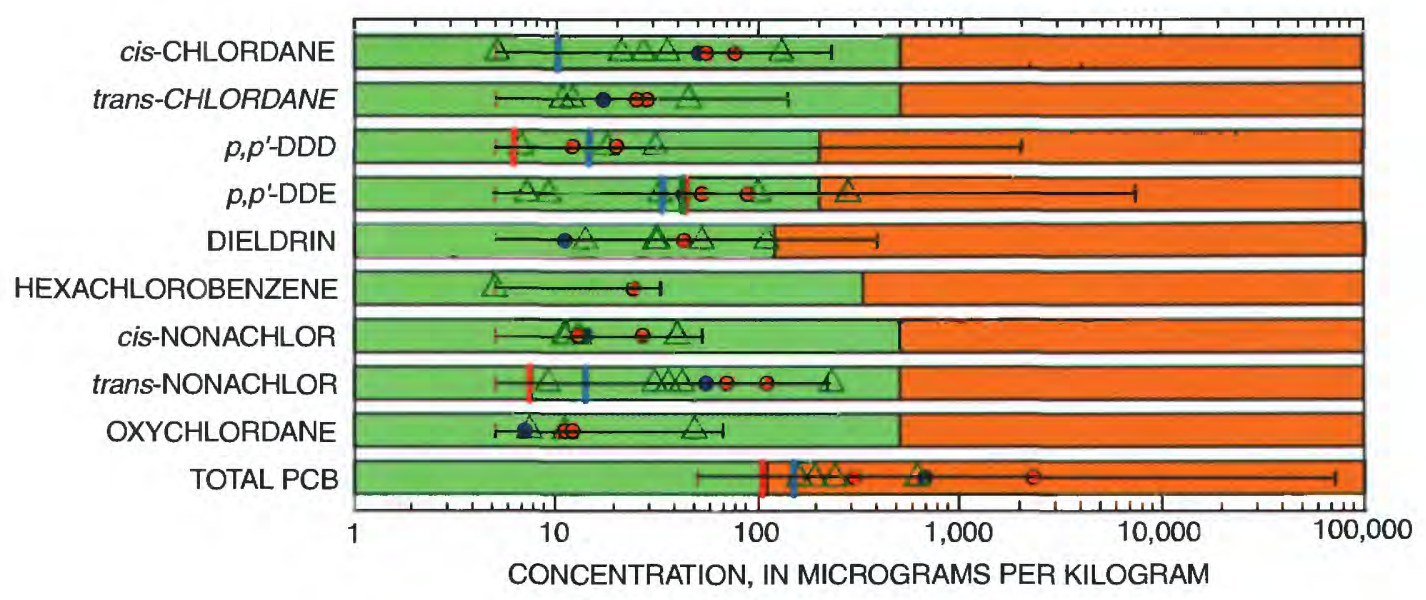

EXPLANATION

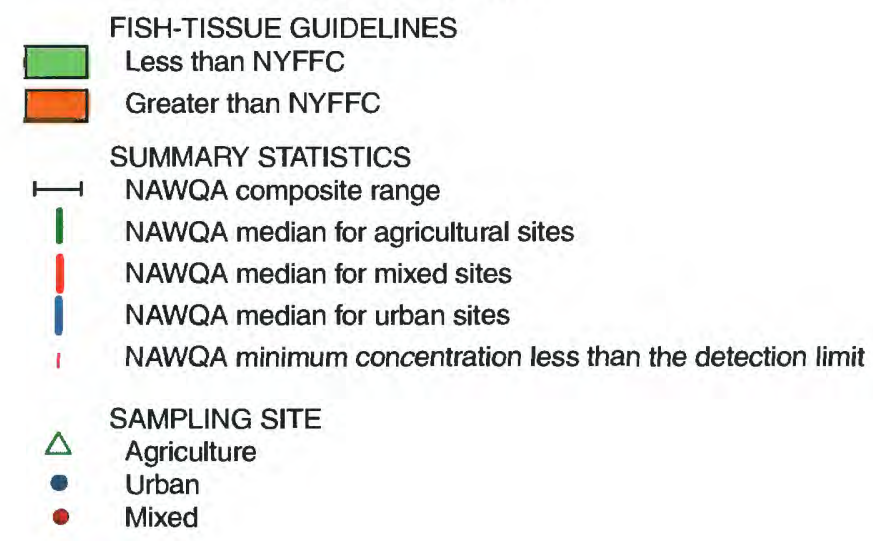

Figure 8. Concentrations of selected organochlorine insecticides and total PCBs at MIAM fish-tissue sites compared to New York Fish Flesh Criteria (NYFFC) and selected 1991 and 1994 national NAWOA study units. 
fourth most common organochlorine insecticide detected in fish tissue. Of chlordane components, cis-chlordane is one of the most abundant (Nowell, 1999). Agricultural and urban land have both contributed to concentrations of this persistent compound in the study unit. Chlordane is commonly associated with urban lawn and garden pesticides and household termite control, as well as an agricultural pesticide, particularly for corn (Eisler, 1985-99). Once in the water column, chlordane readily adsorbs to suspended solids and sediments. Chlordane concentrations tend to be higher in sediments with high organic content (Eisler, 198599). Additional data would be needed to determine whether organic content is a factor affecting sediment chlordane concentrations in the study unit. Eisler (1985-99) states that proximity to pest-control application, fish species feeding habits, and high lipid content are factors in determining chlordane concentrations in biota. Lipid percent in the study unit correlated positively and significantly with chlordane concentration (rho $0.56, p=0.0016$ ) and may be a factor affecting high chlordane detection in fish tissue.

There was no geographic overlap in the sampling sites where sediment and fish-tissue organochlorine insecticide guidelines were exceeded. Few organochlorine insecticides exceeded guidelines in sediment. Exceedances were generally widespread throughout the study unit, with a few concentrated areas on Little Beaver Creek, the Whitewater River below Richmond, and below the confluence of the Stillwater and Mad Rivers with the Great Miami River. In tissue, organochlorine insecticides were commonly detected throughout the study unit. The only tissue-guideline exceedances for DDT were at the Mad River. Higher concentrations of chlordane and DDT were detected at the Mad River sites by both MIAM and state-agency investigations, and chlordane concentrations exceeded national NAWQA maximum concentrations.

Polychlorinated biphenyls . PCBs consist of 209 synthetic halogenated aromatic hydrocarbons, some of which are more commonly known by their industrial trade name, Arochlor. Since 1979, nearly all uses of PCBs and their manufacture have been prohibited in the United States (Eisler, 1985-99). PCBs are especially toxic to wildlife because of their ability to bioaccumulate and biomagnify through the food chain.

Streambed sediment. PCBs were not detected at any of the eight MIAM sediment sites. PCBs were detected at 12 percent of the sites from the 1991 and 1994 national NAWQA studies, with an average concentration of $35.6 \mu \mathrm{g} / \mathrm{kg}$. PELs were exceeded in national NAWQA sites from mixed and urban land use but not in sites from agricultural land use.

In state-agency data, $\mathrm{PCBs}$ were detected at 17 of 188 sites ( 9 percent), 6 of which exceeded the PEL of $277 \mu \mathrm{g} / \mathrm{kg}$ (fig. 9). All elevated PCB concentrations in sediment were from the Great Miami River main stem between Dayton and Hamilton, with the exception of a single site from Little Beaver Creek, a tributary to the Little Miami River. The two highest concentrations were detected at Dicks Creek RM 2.51 and RM 0.93, at 18,330 $\mu \mathrm{g} / \mathrm{kg}$ and $14,300 \mu \mathrm{g} / \mathrm{kg}$, respectively. TELs were exceeded at 11 sites ( 5 percent), 5 from the Great Miami River main stem.

Fish tissue. PCBs were detected at all MIAM fishtissue sampling sites except for the Mad River. Detected concentrations ranged from $160 \mu \mathrm{g} / \mathrm{kg}$ in the Stillwater River to 2,300 $\mu \mathrm{g} / \mathrm{kg}$ in the Great Miami at Hamilton. All MIAM sites, except the Mad River, exceeded the NYFFC guideline concentration of $110 \mu \mathrm{g} / \mathrm{kg}$ for the protection of fish-eating wildlife. PCBs detected at MIAM fish-tissue sites from agricultural, urban, and mixed-land-use settings were compared to 1991 and 1994 national NAWQA concentrations (fig. 8). With the exception of Mad River, concentrations of PCBs at all MIAM sites exceeded national medians. Concentrations from the Stillwater and East Fork Little Miami River sites exceeded the 90th percentile of all national NAWQA agricultural land-use settings, and those at the Whitewater, Great Miami River at Tipp City, and Great Miami River at Hamilton exceeded the 95th percentile for their respective land-use settings.

In state-agency data, concentrations of PCBs at 29 of 36 sites sampled (81 percent) exceeded NYFFC guidelines. Exceedances were found at 7 of 8 ( 88 percent) Little Miami River Basin sites and at 22 of 28 (79 percent) Great Miami River Basin sites. Sites with the highest concentrations were from the Little Miami at Cincinnati-Beechmont Avenue $(1,049 \mu \mathrm{g} / \mathrm{kg})$, Mad River at Huffman Dam $(860 \mu \mathrm{g} / \mathrm{kg})$, and Great Miami River downstream from Dicks Creek $(839 \mu \mathrm{g} / \mathrm{kg})$. Sites with elevated concentrations were in heavily industrialized areas clustered on the Mad River near Springfield and on the Great Miami River between Middletown and Hamilton. All state-agency sites from the Mad River had concentrations of PCBs that exceeded the NYFFC guideline.

Possible sources of PCBs in sediment and tissue. No geographic overlap for PCB exceedances was evident between sediment and tissue sites. PCB concentrations in tissue were detected in 81 percent of state-agency sites and 88 percent of MIAM sites. NYFFC guidelines were exceeded at 36 of 44 sites collected throughout the study unit. Five of six sites with sediment PCB exceedances were on the Great Miami River main stem between Dayton and Hamilton, compared to tissue exceedances, which were common and widespread throughout the study unit. PCBs are hydrophobic and lipophilic (having a strong affinity for lipids), which may be important factors contributing to the high detection of PCBs in fish tissue in the study unit. Hydrophobicity is typically measured by the $\mathrm{n}$-octanol:water partition coefficient $\left(\mathrm{K}_{\mathrm{ow}}\right)$, which is related to the accumulation of nonpolar organic compounds in an organism (Crawford and Luoma, 1994; Okanagan University College, 2002). A higher $\log \mathrm{K}_{\mathrm{ow}}$ value, as found in arochlors 1242,1254 , and 1260 , indicates that the compound is more hydrophobic, and has a 


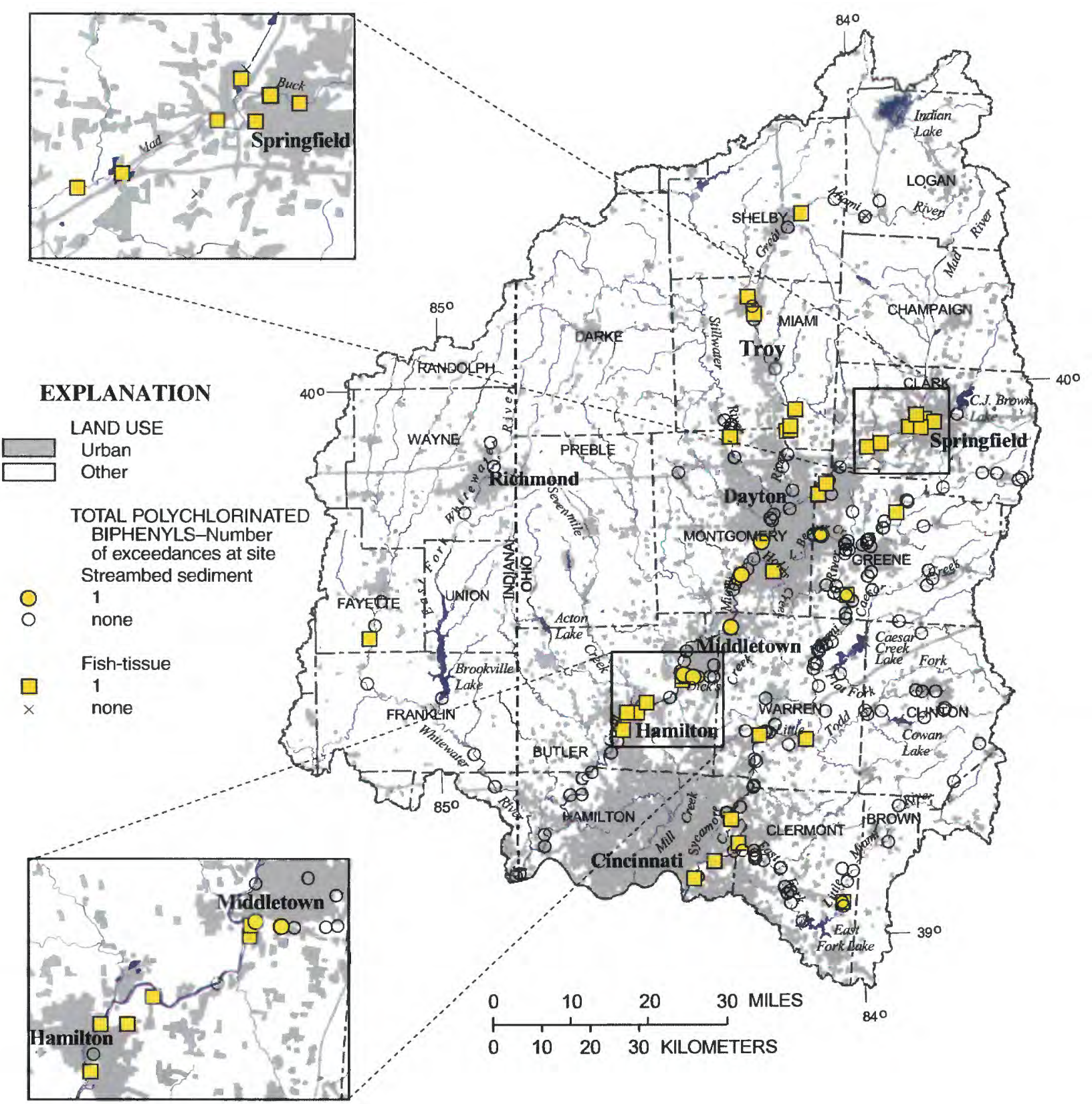

Figure 9. Location of sediment samples exceeding Canadian Sediment-Quality Guideline Probable Effect Levels (PELs) and fish-tissue samples exceeding New York Fish Flesh Criteria (NYFFC) for polychlorinated biphenyls in the Great and Little Miami River Basins, Ohio and Indiana, 1990-98.

higher potential for biological uptake (Eisler, 1985-89). PCBs can accumulate in the lipid-containing tissue of aquatic organisms after uptake across gill membranes or by active uptake through the ingestion of food (Eisler, 198599). Lipid percent correlated positively and significantly with PCB concentration in fish tissue in the MIAM study unit (rho $=0.58, p=0.0028$ ). Between 1985 and 1995, four entities were responsible for 10 or more unauthorized releases of contaminants, including PCB materials in the Great Miami River Basin between Dayton and the mouth near Cincinnati (Ohio Environmental Protection Agency, 1997a). PCB contamination was noted at four NPL sites in the study unit: an incinerator, two landfills, and a chemicalwaste transfer and disposal facilty. 
Semivolatile organic compounds in streambed sediment. SVOCs include polycyclic aromatic hydrocarbons (PAHs), azaarenes, phthalates, phenols, and chlorinated compounds. SVOCs are typically characterized by low to moderate vapor pressures and low solubilities in water. Many are toxic compounds that accumulate in the streambed sediment and, at high concentrations, may become harmful to benthic organisms. PAHs do not bioaccumulate in fish; therefore, tissue samples were not analyzed for SVOCs (Crawford and Luoma, 1994).

Of the 65 SVOCs analyzed in MIAM sediments, 32 were detected. Of these 32, 15 PAHs, 6 alkyl PAHs, 4 phthalates, 2 phenols, 2 azaarenes, 1 quinone, 1 sulfurous-PAH, and 1 nitro-aromatic were detected. The most commonly detected SVOCs were benzo[ $a]$ pyrene, chrysene, bis(2-ethylhexyl)phthalate, fluoranthene, indeno[1,2,3-cd] pyrene, and phenanthrene, which were detected at all eight MIAM sites. The Little Miami River at Milford and Holes Creek sites had the most compounds detected, (28), followed by the Great Miami River at Hamilton, with 26. Among the agricultural sampling locations, Great Miami at Tipp City had the most compounds detected (22), followed by Mad River (19), East Fork Little Miami River (18), and Stillwater River and Whitewater River (14 at each site). Concentrations of pyrene $(518 \mu \mathrm{g} / \mathrm{kg})$ and phenanthrene $(516 \mu \mathrm{g} / \mathrm{kg})$ concentrations were the highest among the PAHs and were detected at Great Miami River at Hamilton. Phenanthrene was the only PAH to exceed a PEL $(515 \mu \mathrm{g} / \mathrm{kg})$. Eight SVOCs were detected at concentrations at or above a TEL. The Little Miami at Milford and the Great Miami at Hamilton had the most TEL exceedances (6) followed by Holes Creek and Great Miami at Tipp City (5), Mad River (4), and East Fork Little Miami River (2).

The increased number of detections and higher concentrations of SVOCs in samples from at the mixed-landuse and urban sites is comparable to the findings of Lopes and Furlong (2001) in their analyses of 1991 national NAWQA SVOC data (fig. 10). Nationally, PAHs were

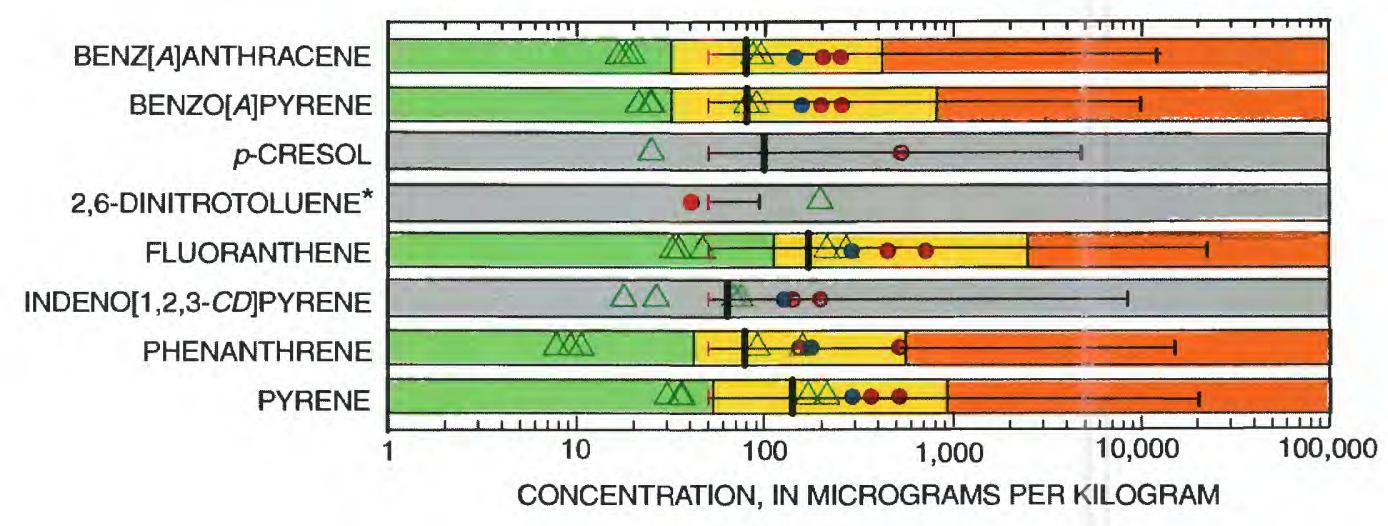

EXPLANATION

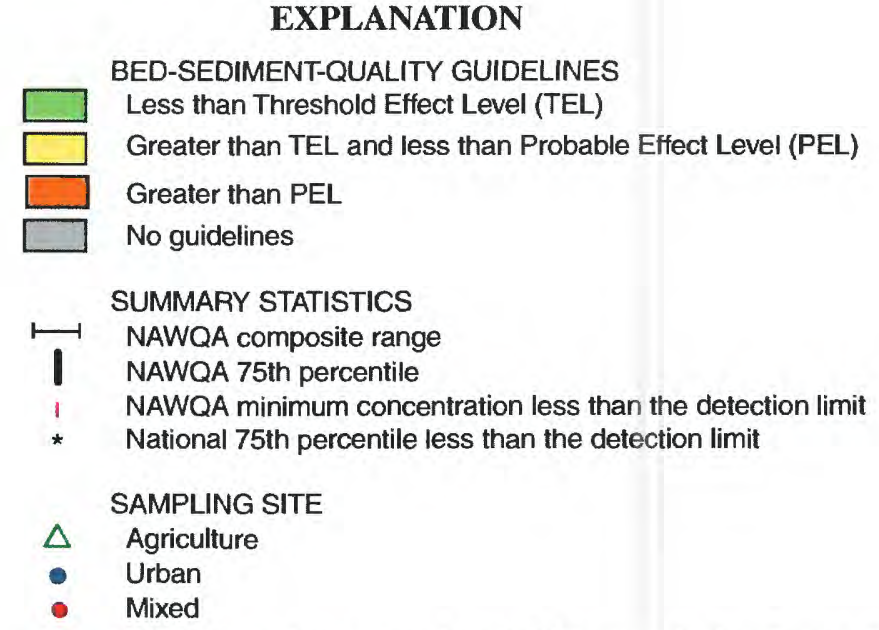

Figure 10. Concentrations of selected semivolatile organic compounds at MIAM streambed-sediment sites compared to Canadian Sediment-Quality Guideline Probable Effect Levels (PELs) and data from selected 1991 NAWOA study units. (Concentrations below $50 \mu \mathrm{g} / \mathrm{kg}$ are estimated values.) 
detected most frequently and at highest concentrations at the urban sites. All MIAM SVOC detections at mixed and urban sites exceeded the national 75th percentile. Concentrations of $p$-cresol and phenanthrene at the Great Miami River at Hamilton exceeded 90th-percentile concentrations. Concentrations of diethyl phthalate at the East Fork Little Miami River (1.7 $\mu \mathrm{g} / \mathrm{kg}$, estimated) and 2,6-dinitrotoluene $(196 \mu \mathrm{g} / \mathrm{kg})$ exceeded the maximum concentration of $<50$ $\mu \mathrm{g} / \mathrm{kg}$ and $93 \mu \mathrm{g} / \mathrm{kg}$, respectively.
For state-agency data, the most commonly detected SVOCs were pyrene, fluoranthene, benzo $[k]$ fluoranthene, benzo[ $b]$ fluoranthene, and phenanthrene $(67,65,68,60$, and 54 sites, respectively). Forty-six of 155 sites exceeded the PEL for SVOCs (fig. 11). A higher proportion of exceedances was found in the Great Miami River Basin (25 of 64 sites, 39 percent) than in the Little Miami River Basin ( 21 of 91 sites, 23 percent), and three or more guidelines were commonly exceeded at each site. The compounds that exceeded PELs most often were PAHs: pyrene (43 sites),

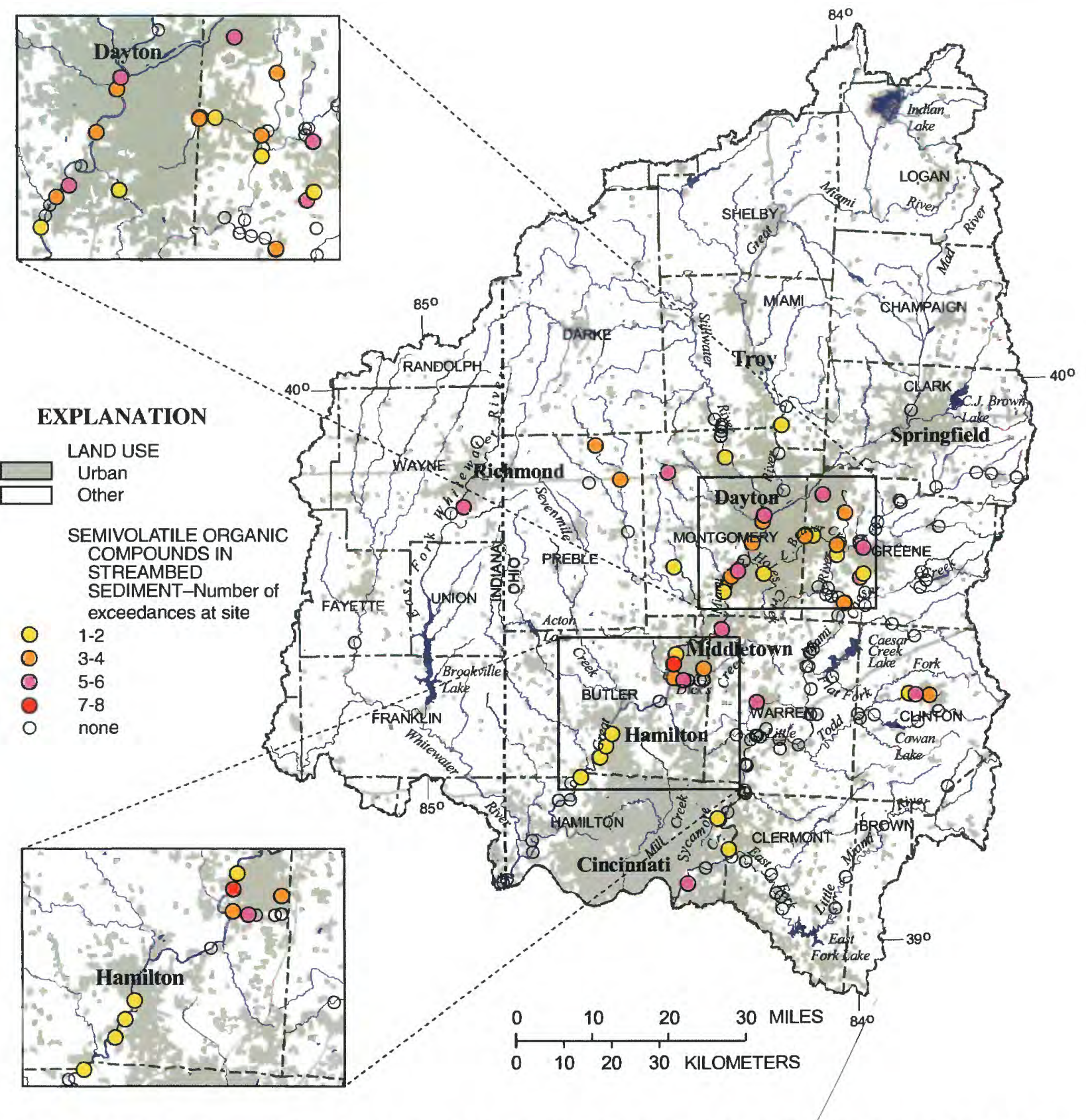

Figure 11. Location of streambed-sediment samples exceeding Canadian Sediment-Quality Guideline Probable Effect Levels (PELs) for semivolatile organic compounds in the Great and Little Miami River Basins, Ohio and Indiana, 1990-98. 
phenanthrene ( 31 sites), chrysene (26 sites), benzo[ $a]$ pyrene (18 sites), and fluoranthene (17 sites). The USEPA lists all of these compounds as hazardous substances. The concentrations of eight of eleven SVOCs detected at the Great Miami River at RM 51.3 exceeded PELs. Seven of $11 \mathrm{com}-$ pounds detected exceeded PELs at Sycamore Creek (RM 0.05 ), a Little Miami River tributary. TELs were most commonly exceeded for fluoranthene ( 66 sites), pyrene ( 58 sites), and chrysene (40 sites).

The higher occurrence of SVOCs, particularly PAHs, at the MIAM urban and mixed-land-use sites compared to agricultural sites can be expected. These sites have the highest percentages of urban land use, and many SVOCs are byproducts of incomplete fossil-fuel combustion and industrial processes. Other sources of SVOCs in the study unit include NPL landfills, incinerators, and liquid-waste disposal facilities. The high detection of PAHs compared to phthalates, phenols, and azaarenes is most likely due to their physical and chemical properties. PAHs are the most hydrophobic and persistent compounds among the SVOCs and are common in fossil fuels. Because of their low solubilities, PAHs tend to partition into sediments and soils. In the study unit, SVOC PELs were frequently exceeded along the Great Miami River main stem south of Dayton and Middletown, and in Little Beaver Creek and Lytle Creek in the upper Little Miami River Basin. The large number of PEL exceedances at the Great Miami River RM 51.3 is likely due to its proximity to an outfall from a major steel company. Discharge from the outfall consists of effluents from the north terminal treatment plant, blast furnace/sinter plant, wastewater treatment plant, and storm water runoff (Ohio Environmental Protection Agency, 1997a). Potential sources of contaminants contributing to high PEL exceedances at Sycamore Creek include a wastewater-treatment plant and sanitary sewer overflows, spills, urban runoff, and sludge deposits (Ohio Environmental Protection Agency, 1997a).

\section{Summary}

In summer 1998, streambed-sediment and fish-tissue samples were collected from eight sites in the Great and Little Miami River Basins (MIAM) study unit of the National Water-Quality Assessment (NAWQA) Program. Samples were analyzed for trace elements and synthetic organic compounds including organochlorine insecticides, polychlorinated biphenyls (PCBs), and other semivolatile organic compounds (SVOCs). Data from investigations by the state agencies, Ohio Environmental Protection Agency (OEPA) and Indiana Department of Environmental Management (IDEM), were incorporated to gain a better perspective of the occurrence and distribution of contaminants in the study unit, and all data were compared to appropriate guidelines to identify elevated contaminant concentrations. Guideline exceedances were plotted on distribution maps to identify sites of potential concern for wildlife health and areas potentially in need of restoration.

All trace elements of interest (arsenic, cadmium, chromium, copper, lead, mercury, nickel, selenium, and zinc) were detected in sediment at the MIAM sites, but no sediment-quality guidelines were exceeded. The most commonly detected trace elements in state-agency sites were zinc, copper, arsenic and cadmium. Probable Effect Levels (PEL, concentrations above which adverse effects are frequently anticipated) in sediment were exceeded at 32 stateagency sites. In sediment, PELs were exceeded for zinc (16 sites), lead (15 sites), arsenic (5 sites), cadmium (5 sites), chromium (3 sites), and mercury (1 site). Areas of higher trace-element concentrations include selected reaches of the Mad River near Springfield, Dicks Creek, and the upper Great Miami River main stem near Troy.

Arsenic, cadmium, copper, mercury, selenium, and zinc were detected at all MIAM fish-tissue sites. Lead was detected at all but the Mad River site. For state-agency data, mercury, cadmium, and lead were detected most often in fish tissue. Detections of trace elements were most frequent on the Mad River near Springfield; Great Miami River main stem near the cities of Middletown, Hamilton and north of Dayton; and along the main stem of the Little Miami River.

Urban and agricultural land uses were both found to contribute to trace-element concentrations in the study unit. Potential sources of trace elements in the study unit include motor-vehicle parts and electronics manufacturers, steel mills, landfills, agricultural pesticides, and feedlots.

Few organochlorine insecticides were detected in sediments and tissue throughout the study unit. At MIAM sites, 31 compounds were analyzed for in sediment, with 5 detected: trans-nonachlor, heptachlor epoxide, cis-chlordane, trans-chlordane, and dieldrin. Heptachlor epoxide was the only insecticide to exceed a recommended guideline: a concentration of $1.1 \mu \mathrm{g} / \mathrm{kg}$ detected at the urban site, Holes Creek, exceeded the Threshold Effect Level (TEL, the concentration below which adverse effects are rarely anticipated) of $0.6 \mu \mathrm{g} / \mathrm{kg}$. All MIAM agricultural sites exceeded the national NAWQA median for dieldrin. At state-agency sites, organochlorine insecticides were detected at 25 sites at levels that may have adverse effects on aquatic organisms. Exceedances of PEL guidelines were more frequent on the Great Miami River south of Dayton and Little Beaver Creek, a Little Miami River tributary. PELs were exceeded for dieldrin, total chlordane, lindane, heptachlor epoxide, DDT, and DDE. Dieldrin PELs and TELs were exceeded most often.

Twenty-seven organochlorine insecticides were analyzed for in MIAM fish-tissue samples, and 11 were detected. Dieldrin, DDE, trans-nonachlor, and cis-chlordane were detected at all eight sites. Concentrations of total 
DDT at Mad River exceeded the New York Fish Flesh Criteria of $200 \mu \mathrm{g} / \mathrm{kg}$. Concentrations of trans-chlordane, cischlordane, trans-nonachlor, and cis-nonachlor at the Mad River exceeded previous study-unit maximum concentrations for agricultural sites. For state-agency data, the most commonly detected organochlorine insecticides were dieldrin, trans-chlordane, DDE, and cis-chlordane. Sites in the Mad River Basin had the highest concentration of DDE and the eight highest $c i s$-chlordane concentrations; the only NYFFC guideline exceedances for total DDT were found at the Mad River near Springfield and Mad River RM 6.2 sites.

Dieldrin was the most commonly detected organochlorine insecticide in sediment and fish tissue, and its PEL was the most frequently exceeded in sediment. More organochlorine insecticides were detected in tissues than in sediment; however, more guidelines were exceeded in sediment. There was no geographic overlap of sediment and fish-tissue sites with respect to elevated organochlorine insecticide concentrations. Exceedances were generally widespread throughout the study unit, with a few concentrated areas on Little Beaver Creek, the Whitewater River below Richmond, and below the confluence of the Stillwater and Mad Rivers with the Great Miami River.

PCBs were not detected at any of the eight MIAM sediment-sampling locations. PCBs were detected at 17 (9 percent) state-agency sites, and concentrations at 6 sites exceeded the PEL. All elevated PCB concentrations in sediment were from the Great Miami River Basin between Dayton and Hamilton, with the exception of a single site on Little Beaver Creek, a tributary to the Little Miami River.

Concentrations of PCBs in fish tissue exceeded the national median and NYFFC guidelines at all MIAM sites except for the Mad River. Concentrations at the Whitewater River, Great Miami at Tipp City, and Great Miami at Hamilton sites exceeded the national NAWQA 95th percentile for their respective land uses. At state-agency sites, 81 percent (36 of 44) of sites sampled exceeded NYFFC guidelines, and all samples from the Mad River were at concentrations that exceeded guidelines. Concentrated areas with guideline exceedances were on the Mad River near Springfield and on the Great Miami River main stem between Middletown and Hamilton.

No distinct geographic overlap for PCB exceedances is evident between sediment and fish-tissue sites. Overall, fish tissue appeared to be a better indicator of PCB contamination than streambed sediment. PCB exceedances in fish tissue were common and widespread throughout the study unit and in similar geographic distributions to trace-element detections. Local sources of PCBs include incinerators, landfills, and chemical-waste transfer and disposal facilities.

Of the 62 SVOCs analyzed for in MIAM sediments, 32 were detected. Most commonly detected SVOCs were benzo[ $a]$ pyrene, chrysene, bis(2-ethylhexyl)phthalate, fluoranthene, indeno $[1,2,3-c d]$ pyrene, and phenanthrene, which were detected at all eight sites. Sites with the most SVOCs
(28) detected were from the Little Miami River at Milford mixed-land-use site and the Holes Creek urban site, followed by the Great Miami River at Hamilton mixed-landuse site. Phenanthrene at the Great Miami River at Hamilton was the only PEL exceedance for SVOCs in the MIAM study. All detections from MIAM mixed- and urban-landuse sites exceeded the national NAWQA 75th percentile. In state-agency sites, the most commonly detected SVOCs were pyrene, fluoranthene, benzo[ $k]$ fluoranthene, benzo[b]fluoranthene, and phenanthrene. SVOC concentrations exceeded PELs at 46 sites. PAH guidelines, particularly for pyrene, were exceeded most often. SVOC PELs were frequently exceeded along the Great Miami River main stem from Dayton to south of Hamilton and in the Upper Little Miami River Basin in Greene County. Three or more SVOC guidelines were commonly exceeded per site. Point sources of SVOCs in the study unit include NPL landfills, an incinerator, liquid-waste disposal facility, and a major steel manufacturer.

\section{References}

Agency for Toxic Substances and Disease Registry, 1993, Toxicological profile for aldrin and dieldrin: Atlanta, Ga., U.S. Department of Health and Human Services, Public Health Service, accessed February 6, 2002, at URL http://www.atsdr.cdc.gov/toxprofiles/ phs1.html\#11

1994, Toxicological profile for chlordane: Atlanta, Ga., U.S. Department of Health and Human Services, Public Health Service, accessed February 6, 2002, at URL http://www.atsdr.cdc.gov/ToxProfiles/ phs8906.html

1996, Toxicological profile for mirex: Atlanta, Ga., U.S. Department of Health and Human Services, Public Health Service, accessed July 29, 2002, at URL http://www.atsdr.cdc.gov/tfacts66.html.

1997, Toxicological profile for hexachlorobenzene: Atlanta, Ga., U.S. Department of Health and Human Services, Public Health Service, accessed July 29, 2002, at URL http://www.atsdr.cdc.gov/tfacts $90 . \mathrm{html}$.

2001a, Public health statement for polychlorinated biphenyls (PCBs): Atlanta, Ga., Agency for Toxic Substances and Disease Registry (ATSDR), Department of Health and Human Services, accessed February 27, 2001, at URL http://www.atsdr.cdc.gov/ToxProfiles/ phs8821.html

2001b, ToxFAQs — frequently asked questions about contaminants found at hazardous waste sites: Atlanta, Ga., Agency for Toxic Substances and Disease Registry (ATSDR), Department of Health and Human Services, accessed August 1, 2002, at URL http://atsdrl .atsdr.cdc.gov/toxfaq.html 
2001c, ToxFAQs for arsenic: Atlanta, Ga., Agency for

Toxic Substances and Disease Registry (ATSDR), Department of Health and Human Services, accessed August 1, 2002, at

URL http://www.atsdr.cdc.gov/tfacts2.html\#isit

Canadian Council of Ministers of the Environment, 1999, Canadian sediment quality guidelines for the protection of aquatic life-Summary tables, in Canadian environmental quality guidelines, 1999: Winnipeg, Canadian Council of Ministers of the Environment, accessed on July 1, 2001, at

URL, http://www.ec.gc.ca/cegg-rcqe/sediment.htm

Crawford, J.K., and Luoma, S.N., 1994, Guidelines for studies of contaminants in biological tissues for the National Water-Quality Assessment Program: U.S. Geological Survey Open-File Report 92-494, 69 p.

Deacon, J.R., and Stephens, V.C., 1998, Trace elements in streambed sediment and fish liver at selected sites in the Upper Colorado River Basin, Colorado, 1995-96: U.S. Geological Survey Water-Resources Investigations Report 98-4124, 19 p.

Debrewer, L.M., Rowe, G.L., Reutter, D.C., Moore, R.C., Hambrook, J.A., and Baker, N.T., 2000, Environmental setting and effects on water quality in the Great and Little Miami River Basins, Ohio and Indiana: U.S. Geological Survey Water-Resources Investigations Report 994201, $98 \mathrm{p}$.

Department of Health and Human Services, National Toxicology Program, 2002, Bioassay of dieldrin for possible carcinogenicity: Research Triangle Park, N.C. National Institute of Environmental Health Sciences (NIEHS), accessed March 19, 2002, at URL http://ntpserver.niehs.nih.gov/htdocs/LT-studies/TR022.html

Eisler, R., 1985-99, Contaminant hazard reviews: Patuxent Wildlife Research Center, accessed March 24, 2001, at URL http://www.pwrc.usgs.gov/

Environmental media services, 2002, Endrin: Washington D.C., accessed July 31, 2002, at

URL http://www.ems.org/sub_chemicals.html

Extoxnet, 2001, Pesticide information profiles: accessed August 25, 2001, at URL http://ace.orst.edu/info/extoxnet/pips/ghindex.html

Forman, W.T., Connor, B.F., Furlong, E.T., Vaught, D.G. and Merten, L.M., 1995, Methods of analysis by the U.S. Geological Survey National Water Quality Laboratory-Determination of organochlorine pesticides and polychlorinated biphenyl in bottom sediment by dual capillary-column gas chromatography with electroncapture detection: U.S. Geological Survey Open-File Report 95-140, 78 p.

Furlong, E. T., Vaught, D.G., Merten, L.M., Forman, W.T., and Gates, P.M., 1996, Methods of analysis by the U.S. Geological Survey National Water Quality Laboratory-determination of semivolatile organic compounds in bottom sediment by solvent extraction, gel perme- ation chromatographic fractionation, and capillary-column gas chromatography/mass spectrometry: U.S. Geological Survey Open-File Report 95-719, 67 p.

Harrington, S.D., 1999, Occurrence and distribution of fish species in the Great and Little Miami River Basins, Ohio and Indiana, pre-1900 to 1998: U.S. Geological Survey Water-Resources Investigations Report 994198, 15 p.

Hirsch, R.M., Alley, W.M., and Wilber, W.G., 1988, Concepts for a national water-quality assessment program: U.S. Geological Survey Circular 1021, 42 p.

Hoffman, G.L., 1996, Methods of analysis by the U.S. Geological Survey National Water Quality Laboratory-Preparation procedure for aquatic biological material determined for trace metals: U.S. Geological Survey Open File Report 96-362, 42 p.

Indiana Department of Environmental Management (IDEM),1992, Biological Studies Section Standard Operating Procedures: Indianapolis, Ind., Office of Water Management, Assessment Branch, Biological Studies Section. 31 p.

1999, Quality Assurance Project Plan For Indiana Surface Water Quality Monitoring Programs, Revision 2: Indianapolis, Ind., Indiana Department of Environmental Management, Office of Water Management, Assessment Branch, $34 \mathrm{p}$.

Irwin, R.J., VanMouwerik, M., Stevens, L., Seese, M.D., and Basham, W., 1997, Environmental contaminants encyclopedia: Fort Collins, Colo., National Park Service, Water Resources Division, accessed August 1, 2002, at URL http://www.nature.nps.gov/toxic/list.html

Larson, S.J., Gilliom, R.J., and Capel, P.D., 1999, Pesticides in streams of the United States-Initial results from the National Water-Quality Assessment Program: U.S. Geological Survey/Water- Resources Investigations Report 98-4222, $92 \mathrm{p}$.

Leiker, T.J., Madsen, J.E., Deacon, J.R., and Foreman, W.T., 1995, Methods of analysis by the U.S. Geological Survey National Water Quality Laboratory-Determination of chlorinated pesticides in aquatic tissue by capillarycolumn gas chromatography with electron-capture detection: U.S. Geological Survey Open-File Report 94$710,42 \mathrm{p}$.

Lopes, T.J., and Furlong, E.T., 2001, Occurrence and potential adverse effects of semi-volatile organic compounds in streambed sediment, United States, 1992-1995: Environmental Toxicology and Chemistry, v. 20, no. 4, p. 727-737.

Lyman, W.J., Glazer, A.E. Ong, J.H., and Coons, S.F., 1987, An overview of sediment quality in the United States: Washington, D.C., U.S. Environmental Protection Agency, EPA-905/9-88-002, 203 p. 
National Institute of Health Sciences, 2002, National Toxicity Program Fact Sheet for diethyl phthalate: Research Triangle Park, N.C., National Institute Health, accessed May 8, 2002, at URL http://ntp-server.niehs.nih.gov/ htdocs/Levels/Tr429levels.Html.

Newell, A.J., Johnson, D.W., and Allen, L.K., 1987, Niagara River Biota Contamination Project-Fish flesh criteria for piscivorous wildlife: New York State Department of Environmental Conservation, Division of Fish and Wildlife, Bureau of Environmental Protection, Technical Report 87-3.

Nowell, L.H., Capel, P.D., and Dileanis, P.D., 1999, Pesticides in stream sediment and aquatic biota-distribution, trends, and governing factors: Boca Raton, Fla., CRC Press, Pesticides in the Hydrologic System series, v. 4, $1,040 \mathrm{p}$.

Ohio Environmental Protection Agency, 1989, Manual of Ohio EPA surveillance methods and quality assurance practices: Columbus, Ohio, Division of Environmental Services.

1995, Laboratory standard operation procedures, organic compounds, v. 3: Columbus, Ohio, Division of Environmental Services.

1996, Ohio EPA sediment sampling guide and methodologies: Columbus, Ohio, $68 \mathrm{p}$.

1997a, Biological and water quality study of the middle and lower Great Miami River and selected tributaries, 1995, Montgomery, Warren, Butler, and Hamilton Counties, Ohio: Columbus, Ohio, Environmental Protection Agency Technical Report, 274 p.

1997b, Manual of laboratory analytical procedures and field practices, metal parameters, v. 2: Columbus, Ohio, Division of Environmental Services, $70 \mathrm{p}$.

Okanagan University College, 2002, Environmental Organic Chemistry, accessed November 12, 2002, at URL http:// www.people.ouc.bc.ca/neggers/Chem\%20317.htm.

Rand, G.M., 1995, Fundamentals of aquatic toxicologyEffects, environmental fate and risk assessment, (2d ed.): Washington D.C., Taylor and Francis, 1,125 p.

Rheaume, S.J., Button, D.T., Myers, D.N., and Hubbell, D.L., 2000 , Areal distribution and concentrations of contaminants of concern in surficial streambed and lakebed sediments, Lake Erie-Lake Saint Clair Drainages, 1990-97: U.S. Geological Survey Water-Resources Investigations Report 00-4200, 60 p.

Rinella, J.F., McKenzie, S.W., Crawford, J.K., Foreman, W.T., Fuhrer, G.J., and Morace, J.L., 1999, Surfacewater-quality assessment of the Yakima River Basin, Washington-Distribution of pesticides and other organic compounds in water, sediment, and aquatic biota, 1987-91, with a section on Dissolved organic carbon in the Yakima River Basin, by George R. Akien: U.S. Geological Survey Water-Supply Paper 2354-B, $180 \mathrm{p}$.
Rowe, G.L., and Baker, N.T., 1997, Great and Little Miami River Basins, National Water-Quality Assessment Program: U.S. Geological Survey Fact Sheet FS-117-97, $4 \mathrm{p}$.

Shelton, L.R., and Capel, P.D., 1994, Guidelines for collecting and processing samples of stream bed sediment for analysis of trace elements and organic contaminants for the National Water-Quality Assessment Program: U.S. Geological Survey Open File Report 94-458, 20 p.

Shelton, L.R., 1994, Field guide for collecting and processing stream-water samples for the National Water-Quality Assessment Program: U.S. Geological Survey OpenFile Report 94-455, 20 p.

Shindel, H.L., Mangus, J.P., and Trimble, L.E., 1999, Water resources data, Ohio, water year 1998, volume 2: U.S. Geological Survey Water Data Report OH-98-2, p. 357367.

U.S. Environmental Protection Agency, 1999, National recommended water quality criteria-Correction: U.S. Environmental Protection Agency, Office of Water, EPA 822-Z-99-001, accessed February 2, 2002, at URL http://www.epa.gov/ost/pc/revcom.pdf

2001, Polychlorinated biphenyls, unified air toxics: Washington, D.C., accessed February 27, 2001, at URL http://www.epa.gov/ttn/uatw/hlthef/polychlo.html

2002a, Superfund National Priorities List sites in Ohio: Washington D.C., Office of Emergency and Remedial Response, accessed February 7, 2002, at http:/ /www.epa.gov/oerrpage/superfund/sites/npl/oh.htm.

2002b, Toxic Release Inventory Explorer: Washington, D.C., Office of Environmental Education, accessed July 16, 2002, at URL http://www.epa.gov/triexplorer/ explorer.htm

2002c, Technology Transfer Network Air Toxics Website, accessed August 5, 2002, at URL http:// www.epa.gov/ttn/atw/hlthef/cresols.html

U.S. Department of Energy, Toxicity profiles: Office of Environmental Management, Oak Ridge Operations (ORO) Office, accessed May 8, 2002, at URL http:// risk.lsd.ornl.gov/tox/rap toxp.shtml

U.S. Geological Survey, 1992, National land cover data, 1992: accessed October 21, 2002, at URL: http:// edc.usgs.gov//products/landcover/nlcd.html.

2001, Tables of standards and guidelines for pesticides in water, bed sediment, and fish tissue-March 2002 Update: accessed March 22, 2001, at URL http://wwwdcascr.wr.usgs.gov/pnsp/criteria

2002, MIAM Web site, accessed July 30, 2002, at URL http://oh.water.usgs.gov/miam.html.

Wentz, D.A., Summary-Mercury in bed sediment and aquatic biota from NAWQA study units: accessed March 22, 2001, at URL http://co.water.usgs.gov/trace/ usgs/summary/bedsed_2p.htm 


\section{Appendix A \\ Results of a national assessment of mercury con- tamination of aquatic ecosystems}

In 1998, the MIAM was one of 21 NAWQA study units across the United States to participate in a national assessment of mercury contamination of aquatic ecosystems (Krabbenhoft and others, 1999). Water, sediment, and smallmouth bass fish-fillet samples were collected at 106 sites representing a variety of land uses. Seven sites were sampled in the MIAM study area. Water and sediment samples were analyzed for total mercury and methylmercury; fish-fillets were analyzed for total mercury only.

Concentrations of total mercury $(3.00 \mathrm{ng} / \mathrm{L})$ and methylmercury $(0.19 \mathrm{ng} / \mathrm{L})$ in MIAM water samples were highest at the Great Miami River at Hamilton site, and they exceeded the national medians of $2.28 \mathrm{ng} / \mathrm{L}$ and $0.06 \mathrm{ng} / \mathrm{L}$, respectively (fig. A1, table A1). Sediment concentrations of methylmercury ranged from $0.17 \mathrm{ng} / \mathrm{g}$ in the Stillwater River to $1.54 \mathrm{ng} / \mathrm{g}$ at Mad River; all sites were below the national median with the exception of Great Miami River at Hamilton and Mad River. All MIAM sediment concentrations of total mercury were below the national median with the exception of the mixed-land-use site Great Miami River at Hamilton. MIAM fish-fillet concentrations ranged from $0.04 \mu \mathrm{g} / \mathrm{g}$ at Little Miami River at Milford to $0.52 \mu \mathrm{g} / \mathrm{g}$ at the East Fork Little Miami River at Williamsburg. All three fillets from the agricultural site East Fork Little Miami River exceeded the national median for smallmouth bass fillet composite of $0.205 \mu \mathrm{g} / \mathrm{g}$. The national median was also exceeded in fillet samples from the Mad River $(0.27 \mu \mathrm{g} / \mathrm{g})$ and Little Miami River at Milford $(0.278 \mu \mathrm{g} / \mathrm{g})$. The Food and Drug Administration action level $(1 \mu \mathrm{g} / \mathrm{g})$ for mercury concentrations in fish fillets was not exceeded at any MIAM site (Food and Drug Administration, 2003).

Statistical analyses of methylmercury concentrations from the 21 study units found stronger correlations between fish fillet and water than between fish fillet and sediment (Brumbaugh and others, 2000). At low total mercury concentrations, methylmercury production and total mercury concentrations are proportional (Krabbenhoft and others, 1999). Further information on this study can be found in Krabbenhoft and others (1999) and Brumbaugh and others (2000)

Mercury has no known biological function and is potentially hazardous to all living organisms. For fish species, it is the most toxic trace element. Fish exposure is predominantly through the diet but also may be through the gills. Mercury, unlike other trace elements, has a tendency to accumulate at higher concentrations in fish muscle than in liver or kidneys (Maret and Dutton, 1998). Mercury bioconcentrates and then biomagnifies throughout the food chain; therefore, predator species at the top of the food web generally have higher concentrations in their bodies than their prey do. Effects of mercury poisoning in fish include reduced reproductive success, impaired growth, and developmental and behavioral abnormalities (Eisler, 1985-99). Methylmercury is the most common organic form of mercury. It has a strong affinity for proteins and accounts for 90-100 percent of the total mercury found in fish tissue (Eisler, 1985-99) .

\section{Appendix references}

Brumbaugh, W.G., Krabbenhoft, D.P., Helsel, D.R., and Wiener, J.G., 2000, A national pilot study of mercury contamination of aquatic ecosystems along multiple gradients-Bioaccumulation in fishes, 21st annual meeting of the Society of Environmental Toxicology and Chemistry (SETAC), November 12-16, 2000, Nashville Tenn.: p. 4.

Eisler, R., 1985-99, Contaminant hazard reviews: Patuxent Wildlife Research Center, accessed March 24, 2001, at URL http://www.pwrc.usgs.gov/

Food and Drug Administration, 2003, Pesticide residues in food and feed-Enforcement criteria: FDA compliance policy guide 7141.01 , accessed January 15, 2003, at URL http://www.fda.gov/ora/complianceref/cpg/cpgfod/cpg575-100.html

Krabbenhoft, D.P., and Rickert, D.A., 1997, Mercury contamination of aquatic ecosystems: U.S. Geological Survey, accessed August 1, 2002, at URL http://wi.water.usgs.gov/pubs/FS-216-95/

Krabbenhoft, D.P., Wiener, J.G., Brumbaugh, W.G., Olson, M.L. DeWild, J.F., and Sabin, T.J., 1999, A national pilot study of mercury contamination of aquatic ecosystems along multiple gradients, in Morganwalp, D.W., and Buxton, H.T., eds., 1999, U.S. Geological Survey Toxic Substances Hydrology Program-Proceedings of the Technical Meeting, Charleston, South Carolina, March 8-12, 1999-Volume 2-Contamination of hydrologic systems and related ecosystems: U.S. Geological Survey Water-Resources Investigations Report 99-4018B, p. 147-160.

Maret, T.R., and Dutton, D.M., 1998, Summary of information on synthetic organic compounds and trace elements in tissue of aquatic biota, Clark Fork-Pend Oreille and Spokane River Basins, Montana, Idaho, and Washington, 1974-96, U.S. Geological Survey Water-Resources Investigations Report 98-4254, 55 p. 


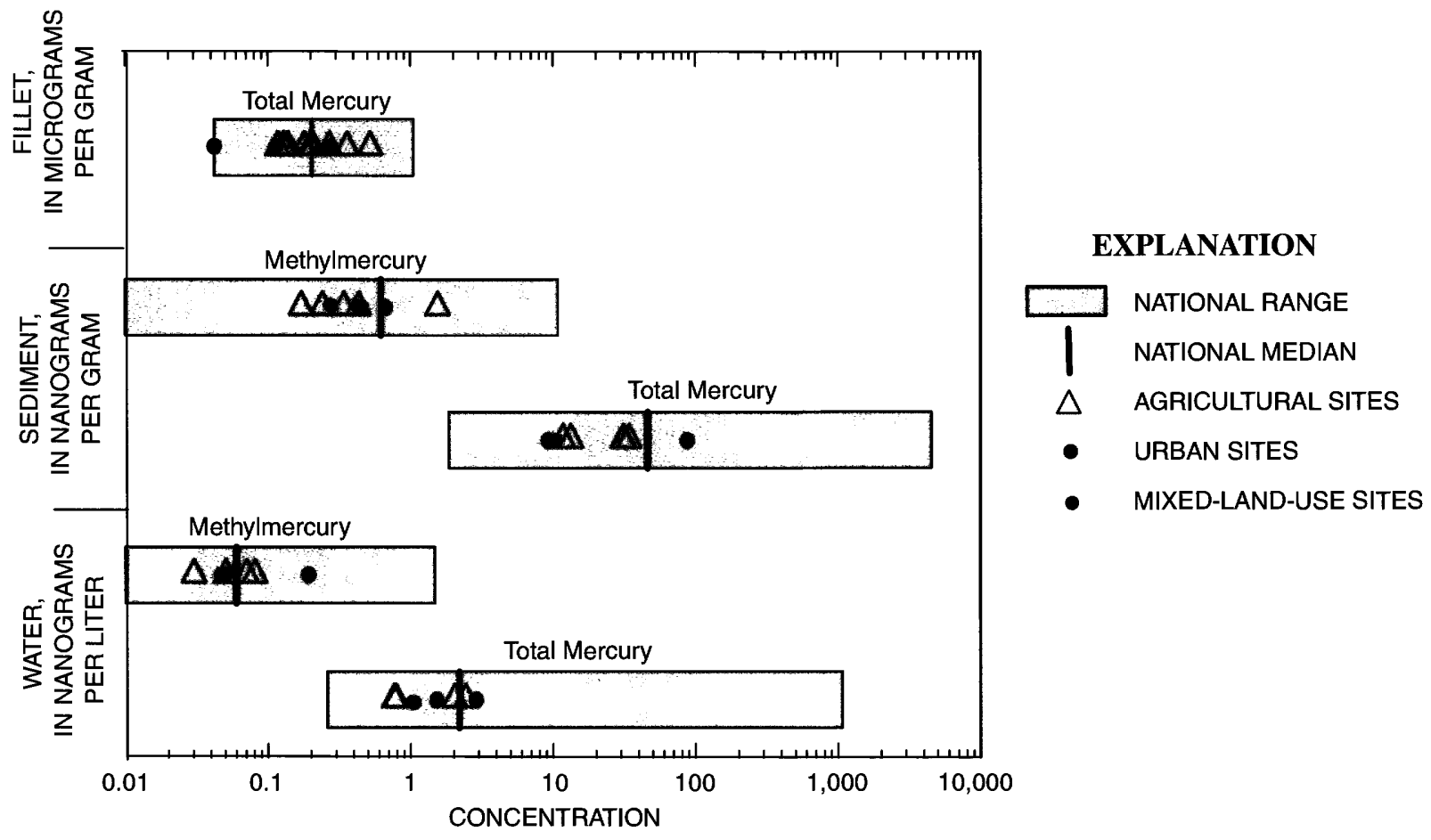

Figure A1. Comparison of mercury concentrations in fish-fillet samples in the Great and Little Miami River Basins study unit to range and median concentrations from 21 NAWQA study units (MIAM included). (Fish-tissue fillet concentrations are shown for each fish analyzed.)

Table A1. Mercury concentrations in fish fillets, bed sediment, and surface water at selected sampling locations in the Great and Little Miami River Basin

[g, grams; $\mu \mathrm{g} / \mathrm{g}$, microgram per gram; ng/g, nanograms per gram ; ng/L, nanograms per liter. Additional station location information can be found in figure 1 and table 1 of the main text.]

\begin{tabular}{|c|c|c|c|c|c|c|c|c|}
\hline Station number & $\begin{array}{l}\text { Number } \\
\text { of fish }\end{array}$ & \multicolumn{3}{|c|}{ Fish fillet } & \multicolumn{2}{|c|}{ Bed sediment } & \multicolumn{2}{|c|}{ Surface water } \\
\hline 03245500 & 3 & 55 & 1.5 & 0.04 & 9.20 & 0.45 & 1.57 & 0.05 \\
\hline 03245500 & 1 & 698 & 5.5 & 0.28 & 9.20 & 0.45 & 1.57 & 0.05 \\
\hline 03246400 & 1 & 107 & 2.5 & 0.20 & 13.30 & 0.24 & 2.09 & 0.07 \\
\hline 03246400 & 1 & 608 & 4.5 & 0.52 & 13.30 & 0.24 & 2.09 & 0.07 \\
\hline 392246084340100 & 1 & 345 & 3.5 & 0.11 & 87.20 & 0.67 & 3.00 & 0.19 \\
\hline 393259085101200 & 1 & 80 & 2.5 & 0.14 & 11.70 & 0.43 & 0.81 & 0.03 \\
\hline 393259085101200 & 1 & 129 & 2.5 & 0.13 & 11.70 & 0.43 & 0.81 & 0.03 \\
\hline 395534084091400 & 4 & 178 & 3.5 & 0.12 & 31.40 & 0.34 & 2.52 & 0.05 \\
\hline 395534084091400 & 1 & 518 & 5.5 & 0.27 & 30.80 & 1.54 & 0.79 & 0.08 \\
\hline
\end{tabular}

